IZA DP No. 5002

Education and Family Background:

Mechanisms and Policies

Anders Björklund

Kjell G. Salvanes

June 2010 


\title{
Education and Family Background: Mechanisms and Policies
}

\author{
Anders Björklund \\ SOFI, Stockholm University \\ and IZA \\ Kjell G. Salvanes \\ Norwegian School of Economics and Business Administration, \\ CEE, CESifo and IZA
}

\section{Discussion Paper No. 5002 \\ June 2010}

IZA

P.O. Box 7240

53072 Bonn

Germany

Phone: +49-228-3894-0

Fax: +49-228-3894-180

E-mail: iza@iza.org

\begin{abstract}
Any opinions expressed here are those of the author(s) and not those of IZA. Research published in this series may include views on policy, but the institute itself takes no institutional policy positions.

The Institute for the Study of Labor (IZA) in Bonn is a local and virtual international research center and a place of communication between science, politics and business. IZA is an independent nonprofit organization supported by Deutsche Post Foundation. The center is associated with the University of Bonn and offers a stimulating research environment through its international network, workshops and conferences, data service, project support, research visits and doctoral program. IZA engages in (i) original and internationally competitive research in all fields of labor economics, (ii) development of policy concepts, and (iii) dissemination of research results and concepts to the interested public.
\end{abstract}

IZA Discussion Papers often represent preliminary work and are circulated to encourage discussion. Citation of such a paper should account for its provisional character. A revised version may be available directly from the author. 
IZA Discussion Paper No. 5002

June 2010

\section{ABSTRACT \\ Education and Family Background: Mechanisms and Policies*}

In every society for which we have data, people's educational achievement is positively correlated with their parents' education or with other indicators of their parents' socioeconomic status. This topic is central in social science, and there is no doubt that research has intensified during recent decades, not least thanks to better data having become accessible to researchers. The purpose of this chapter is to summarize and evaluate recent empirical research on education and family background. Broadly speaking, we focus on two related but distinct motivations for this topic. The first is equality of opportunity. Here, major the research issues are: How important a determinant of educational attainment is family background, and is family background - in the broad sense that incorporates factors not chosen by the individual - a major, or only a minor, determinant of educational attainment? What are the mechanisms that make family background important? Have specific policy reforms been successful in reducing the impact of family background on educational achievement? The second common starting point for recent research has been the child development perspective. Here, the focus is on how human-capital accumulation is affected by early childhood resources. Studies with this focus address the questions: what types of parental resources or inputs are important for children's development, why are they important and when are they important? In addition, this literature focuses on exploring which types of economic policy, and what timing of the policy in relation to children's social and cognitive development, are conducive to children's performance and adult outcomes. The policy interest in this research is whether policies that change parents' resources and restrictions have causal effects on their children.

JEL Classification: $\quad$ 121, J13, J24

Keywords: intergenerational mobility, sibling correlations, education, education reform

Corresponding author:

Kjell G. Salvanes

Department of Economics

Norwegian School of Economics

and Business Administration

Helleveien 30

N-5035 Bergen-Sandviken

Norway

E-mail: kjell.salvanes@nhh.no

\footnotetext{
* This paper has been prepared for the Handbook of the Economics of Education. We thank participants at the Handbook of Economics of Education conference at CESifo in Munich in September 2009 for discussions and comments. Björklund acknowledges financial support from the Swedish Council for Working Life and Social Research (FAS). Salvanes acknowledges the support from the Norwegian Research Council.
} 


\section{Contents}

1. Background and motivation

2. How important is family background for final educational attainment?

3. Theory: a taxonomy of effects

4. How the family affects the child

4.1 Nature and nurture

4.2 The causal effect of parental education levels on their offspring

4.2.1 Framework

4.2.2 Adopted children

4.2.3 Twins as parents

4.2.4 Natural experiments

4.2.5 Discussion of results

4.3 Money and time as parental inputs

4.3.1 Early learning: critical periods and dynamic complementarities

4.3.2 Family size and birth-order effects

5. What education policy can do at different stages of the educational career: lessons from research on reforms

5.1 Maternity leave and preschool reforms

5.2 Comprehensive school reforms and tracking

6. Conclusions 


\section{Background and motivation}

In every society for which we have data, people's educational achievement is positively correlated with their parents' education or with other indicators of their parents' socioeconomic status. This pattern has fascinated many scholars, with early seminal contributions in sociology by, for example, James Coleman (1966) in the so-called Coleman report, and in economics by, for example, Gary Becker (1964). The topic has also arisen frequently in policy debates, and most democratic societies have adopted policies aimed at reducing the impact of family background on educational attainment. Although the topic is classical and central in social science, there is no doubt that research in this area has intensified during recent decades and even during the past few years, not least thanks to better data having become accessible to researchers. ${ }^{1}$ The purpose of this chapter is to summarize and evaluate recent research on education and family background.

To put this research into perspective, it is useful to make a distinction between two different, though related, motivations for the study of educational attainment and family background. One common starting point is equality of opportunity. Here, family background is relevant because the individual has not chosen his or her family background and thus cannot be held accountable for any impact of family background on his or her status during adulthood. Therefore, the more important family background isfor instance, as measured by parental education—for final educational achievement, the

\footnotetext{
${ }^{1}$ See Björklund and Jäntti (2009) and Black and Devereux (2010) for recent reviews of intergenerational transmission of income and education. Blanden, Gregg and MacMillan (2010) and Erikson and Goldthorpe (2010) offer an illuminating discussion of the relative merits of intergenerational income and class mobility.
} 
less equality of opportunity there is. ${ }^{2}$ This reasoning has motivated many education policy reforms that aim to reduce the association between educational attainment and family background. Indeed, it has often been claimed that some reforms might enhance equality as well as efficiency. Perhaps the most notable example is the elimination of credit constraints for young people's educational decisions. For instance, if ability is distributed more evenly in the population than the availability of resources for funding education, there is clearly an argument for reducing credit constraints for the poor. Without well-functioning credit markets, many productive investments in human capital might not take place.

This kind of reasoning raises several research questions. A first basic question is: how important a determinant of educational attainment is family background? Is family background — in the broad sense that incorporates factors not chosen by the individual—a major, or only a minor, determinant of educational attainment? The great policy interest in this topic has motivated studies of whether specific policy reforms have been successful in reducing the impact of family background on educational achievement. The second common starting point for recent research has been a child development perspective. Here, economists consider the parents as major actors who

\footnotetext{
${ }^{2}$ Of course, there is not necessarily a one-to-one link between the typical statistics on the role of family background, such as intergenerational correlations, and equality of opportunity. For instance, Jencks and Tach (2006) make the point that the typical statistics on the role of family background measure the fraction of total inequality that is attributed to family background. Thus, for example, obvious improvements in equality of opportunity might reduce both the nominator and the denominator of the statistic, with ambiguous overall effects on the statistic. Further, all sources of family background effects do not violate norms of equality of opportunity equally. Jencks and Tach (2006) argue that causal effects of parental income strongly violate such norms. This argument underscores the importance of learning what mechanisms underlie the impact of family background. See also Roemer (1998) for a normative approach to equality of opportunity. Another strand of the equality literature focuses on the importance of economic incentives in modifying the degree of social mobility; perfect intergenerational mobility is not clearly not optimal (Phelan, 2006; Atkeson and Lucas, 1992).
} 
combine their resources and invest in their children's future earnings capacity via the children’s educational attainment. ${ }^{3}$ More generally, this literature has as its starting point the position that there are determinants of children's outcomes such as: 1) parents' choices, in terms of investment in the production of children's human capital (as well as other circumstances and choices); 2) the choices that children make given the investment parents have undertaken; and 3) policies the government undertakes in determining the environment for parents and children.

Studies with this focus address the questions of what type of parental resources or inputs are important for children's development, why they are important and when they are important (see, for instance, Conti, Heckman and Zanolini, 2009, and Currie, 2009). This literature also focuses on which types of economic policy, and what timing of policy in relation to children's social and cognitive development, are conducive to children's performance and adult outcomes. The policy interest in this research is whether policies that change parents' resources and restrictions have causal effects on their children. A common example is whether reforms that raise the educational attainment of women (mothers) have effects on their children. Other examples are the appropriate timing of parents' investments in children's outcomes and the complementarity of investments at different periods for children. In addition, much of the recent program-evaluation literature has focused particularly on the effectiveness of targeted programs for deprived children.

The intention of this chapter is thus to offer a summary and evaluation of the literature based on both these viewpoints and on these two important strands of the

3 See Haveman and Wolfe (1995) for a general overview of this literature emphasizing a whole set of child outcomes. See Oreopoulos and Salvanes (2010) for a recent overview and analysis. 
literature. In Section 2, we commence by addressing the question of how important family background—in the broad sense of incorporating both the family and the neighborhood—is for inequality of final educational attainment. We perform this analysis by investigating sibling correlations that tell us how much of the inequality in educational attainment is accounted for by factors that siblings share. Our conclusion is that, in all countries for which we have data, more than $50 \%$ of the variation in years of schooling can be attributed to factors shared by siblings. We argue that this is a sizable percentage that should motivate the search for a deeper understanding of what these factors are. On the other hand, the explanatory power of parental education is much lower, generally below $20 \%$.

Given the importance of family background in explaining educational outcomes, we sketch a conceptual framework in Section 3, describing mechanisms that may explain children's outcomes. In Section 4, we provide an overview of the literature on the different types of inputs into the family production process for human capital for the next generation. After presenting the literature on the importance of nature and nurture, we focus our attention on the attempts in the literature to evaluate the causal effect of parental inputs. Further, a special focus is given to the recent literature on the causal effect of parental education on children's education. Then, we discuss other types of parents' investments, including resources in terms of time and money, as well as fertility decisions that indirectly determine resources available, such as family size and the birth order of children. In Section 5, we present results from the recent literature on economic reforms that target children's outcomes. In this section, we focus on the different policy instruments that governments use to establish the general environment for parents' and 
children's decisions. In particular, we offer an overview of the results with regard to family and education policies that affect parents' resource use or inputs in the family production function, and which provide an environment for children's educational choices. The chapter ends with concluding remarks in Section 6.

\section{How important is family background for final educational attainment?}

The purpose of this section is to demonstrate the importance of family background factors for educational attainment in modern societies. At the outset, we want to stress two major limitations in our exposition. First, we focus on final educational attainment, which is natural from an equality-of-opportunity point of view. However, intermediate outcomes such as grades and test scores are often useful when analyzing the timing of educational interventions. Our framework below is relevant for such outcomes as well. See Hanushek and Woessman (2010, section 4.2) for an introduction to test scores and family background. Second, to keep the exposition simple, we apply years of schooling as our measure of final educational attainment.

Our point of departure is the fact that a sibling correlation is a broad measure of family background and neighborhood factors. To see this, consider years of schooling, $S_{i j}$, of sibling $j$ in family $i$ :

$$
S_{i j}=a_{i}+b_{i j}
$$

where the family component, $a_{i}$, represents what siblings have in common, and the sibling-specific component, $b_{i j}$, denotes the effect of factors that are idiosyncratic to 
sibling $j$. Because the two components are orthogonal by construction, we can decompose the schooling variance as:

$$
\sigma_{S}^{2}=\sigma_{a}^{2}+\sigma_{b}^{2}
$$

providing the following expression for the sibling correlation in education:

$$
\operatorname{Corr}\left(S_{i j}, S_{i j^{\prime}}\right)=\rho_{S I B}=\operatorname{Cov}\left(S_{i j}, S_{i j^{\prime}}\right) / \sigma_{S}^{2}=\sigma_{a}^{2} /\left(\sigma_{a}^{2}+\sigma_{b}^{2}\right)
$$

Thus, the sibling correlation tells us what fraction of the total variance of years of schooling is attributable to factors that siblings share. Such factors can be of many different types, and include common genes, a common environment and the influence of one sibling on another. A common environment in turn includes the within-family environment as well as the neighborhood environment, including, for example, shared school quality. Although the shared family component captures many factors, it does not pick up all family background influences. For example, genetic traits not shared by siblings, differential treatment of siblings and time-dependent changes in the family, as well as neighborhood factors, will show up in the individual component, even though they are part of the individual's family and community background. Therefore, we must interpret the sibling correlation as a lower bound estimate of the impact of a broad set of family and neighborhood background factors.

How large is this lower bound in different countries? In Table 1, we have collected a set of estimated sibling correlations for different countries. Neglecting first 
correlations among twin siblings, we find that the correlations are generally quite large, typically in the range $0.40-0.60$. The estimates are typically somewhat higher in the US than in European countries. The lowest correlations are reported for former East Germany, where they are in the range $0.25-0.30$. It is noteworthy, however, that the correlations were low for the early cohorts born around 1930, who grew up before the formation of the former German Democratic Republic. Further, for most countries, the estimates have been quite constant over time. For instance, Sieben, Huinink and de Graaf (2001) report that the decline in the Netherlands is not statistically significant. Some of the recent estimates for the US are above 0.6, whereas those for Germany and the Netherlands fall in between the US and Nordic estimates. For the cases with separate estimates for brothers and sisters, there are no striking gender differences.

From these results, we conclude that a lower bound on the share of variation in years of schooling that is attributable to common family and community background factors is between $40 \%$ and $65 \%$. These percentages strike us as high. How important are the family and community factors that are not shared by siblings? We now discuss two sources of such nonshared factors, namely nonshared genes and so called birth-order effects.

According to standard genetic models, full biological siblings share only $50 \%$ of their genes, and each individual obtains $100 \%$ of his or her genes from his or her parents. Therefore, one approach would be to consider correlations among monozygotic (MZ) twins, or identical twins, so called because they have identical genes. One could argue that such correlations provide more reliable estimates of what we are looking for than do correlations of nontwin siblings. However, a caveat is that MZ twins might be 
particularly affected by interactions between themselves, and that such interactions might have no counterpart for nontwins and thus for the majority of the population. One could therefore argue that a correlation among MZ twins represents a (potential) upper bound on the share of variation in years of schooling that is attributable to family and community background.

In Table 1, we report some estimates for twins. These numbers are strikingly higher than those for the nontwins, in the range $0.70-0.76$, suggesting that around $75 \%$ of the variation in years of schooling might be due to factors in the family and the community.

Is it likely that these correlations overstate the importance of family background because of an interaction between $\mathrm{MZ}$ twins that is not representative for the majority of the population? One way to shed some light on this issue would be to compare the correlations among dizygotic (DZ) twins with closely spaced—separated by, say, four years or less - full biological (but nontwin) siblings and with more widely spaced full biological siblings. The argument is that if interaction between the siblings is an important source of sibling similarity, we would expect higher correlations among DZ twins than among closely spaced full biological siblings, and even lower correlations among widely spaced siblings. Of course, other mechanisms, such as exposure to different shocks in the family and the neighborhood, might also create such a pattern. Nonetheless, similar correlations among these three sibling types would be suggestive of low interaction effects.

In Table 2, we report estimated sibling correlations for these three sibling types. For Norway and the US, we do not find any substantial differences between closely 
spaced and widely spaced siblings. This result suggests that, among nontwin siblings, it is permanent family background factors that are shared and not time-specific ones. For Norway, however, we find a substantial difference between closely spaced nontwin siblings and DZ twins. This result definitely suggests that there is a more intensive interaction between twin siblings than between siblings in general, a result that in turn calls for care when using twins as a natural experiment in family background studies. We return to this issue when we discuss studies regarding nature-nurture decomposition in Section 4.1.

Yet another reason why the sibling correlation represents a lower bound estimate of family background factors not chosen by the individual is that the correlation only captures a common family component, which is shared by the siblings used in the estimation of the variance components. Recent research has shown that there is also a systematic effect of birth order; see section 4.3.2 for a longer exposition. Such an effect is not part of the common family component that is used to compute the sibling correlations above. Using Norwegian data on within-family variation, Black, Devereux and Salvanes (2005a) estimate that in families with two children, the second-born child has 0.4 years less schooling than the firstborn child and, in families with three children, the difference between the firstborn and last-born children's schooling is as high as 0.6 years. Booth and Kee (2009), applying a different empirical strategy using British data, also find a significant birth-order effect with the same pattern, although lower in magnitude. These results demonstrate that the sibling correlations estimated above are lower bound estimates of the full impact of family background. ${ }^{4}$

\footnotetext{
${ }^{4}$ It strikes us as an important task to extend the conventional variance-component approach underlying
} 
Next, we turn to intergenerational correlations in years of schooling. To show that a sibling correlation is a broader measure of the importance of family and community background, we start by showing the formal relationship between a sibling and an intergenerational correlation. Because the individual component in equation (1) is orthogonal to the family component, only the latter component can be related to parental education. Let this relationship be:

$$
a_{i}=\beta S_{i}^{p}+z_{i},
$$

where $S_{i}^{p}$ is parental years of schooling in family $i$, and $\mathrm{z}_{\mathrm{i}}$ denotes family factors that are orthogonal to parental years of schooling. Inserting (4) into (1), we obtain:

$$
S_{i j}=\beta S_{i}^{p}+e_{i j}
$$

where $e_{i j}=z_{i}+b_{i j}, \operatorname{Cov}\left(S_{i}^{p}, e_{i j}\right)=0$ and $\beta$ is the intergenerational regression coefficient. In the case where we standardize years of schooling in both generations, $\beta$ is also the intergenerational correlation coefficient. From (4), we have:

$$
\sigma_{a}^{2}=\beta^{2} \sigma_{S^{p}}^{2}+\sigma_{z}^{2}
$$

Dividing through by $\sigma_{S}^{2}$, we obtain:

estimates of sibling correlations to incorporate the role of birth-order effects. 


$$
\frac{\sigma_{a}^{2}}{\sigma_{s}^{2}}=\beta^{2}\left(\frac{\sigma_{s}^{2}}{\sigma_{s}^{2}}\right)+\frac{\sigma_{z}^{2}}{\sigma_{s}^{2}}=\rho_{S I B}=\rho_{I G}^{2}+\frac{\sigma_{z}^{2}}{\sigma_{s}^{2}}
$$

Thus, we find that the sibling correlation is a broader measure of the impact of family background than (the squared) intergenerational correlation because the sibling correlation also captures factors that are unrelated to parental schooling.

We now turn to Table 3, which contains a set of intergenerational correlations for different countries. We see that these are in the range from 0.30 (Denmark) to 0.46 (US). Obviously, the square of these numbers gives us the share of variance that is explained statistically by parental schooling. Then, we obtain a range from 0.09 to 0.21 . Thus, factors that are not even correlated with parental schooling dominate among the factors shared by siblings.

It would also be constructive to know whether the factors contributing to the high sibling correlations are to be found initially within the family or in the characteristics of the neighborhood where the children have grown up. Studies using an original approach by Solon, Page and Duncan (2000) indicate that the family is the most important factor. The approach is as follows. First, use data that identify whether individuals grew up in the same close neighborhood without belonging to the same family. Second, estimate a variance-component model with one component for the neighborhood and one orthogonal component for the individual. These variance components also define a correlation among persons growing up in the same neighborhood. The neighborhood component will capture not only pure neighborhood effects but also the effects of the family. Because there is presumably a tendency for advantaged families to live in advantaged neighborhoods, the neighborhood component will be an upwardly biased estimate of true 
neighborhood effects. Thus, the neighborhood correlation is also an upward bounded estimate of a pure neighborhood correlation. If such an upper bound on the relative importance of neighborhood effects is low compared with a corresponding sibling correlation, one can infer that family factors are more important than neighborhood factors for observed sibling similarities.

In Table 4, we report results from three studies using this approach, for the US, Norway and Sweden. All three studies reveal the same pattern, namely that the upwardly biased neighborhood correlations are very low compared with the corresponding sibling correlation. The relatively largest neighborhood correlation is reported for the US, where it amounts to around $30 \%$ of the sibling correlation.

Three broad conclusions result from this section. First, something in the family background has sizable effects on final education. Factors shared by siblings account for at least $40 \%$ to $60 \%$ of the overall variation in years of schooling. This range is probably a lower bound estimate because siblings share only 50\% of their genes with each other, but each individual obtains all of his or her genes from his or her parents. Further, differential effects, such as birth-order effects, are not taken into account by the sibling correlation approach. Such differential effects are obviously part of family background and not chosen by the individual. Second, parental years of schooling account for only a minor part of the factors that siblings share. Indeed, more than half of the factors that siblings share are not even correlated with parental years of schooling. Third, neighborhood effects account for, at most, around a third of the factors that siblings share. This shows that we should initially look for family rather than neighborhood factors to 
explore in more detail what are the most important factors that siblings share. From now on, we turn our focus to such family factors.

\section{Theory: a taxonomy of effects}

The economic literature on intergenerational transmission has emphasized the importance of family background for children's educational outcomes. In addition, as we have seen from Table 3, the raw intergenerational correlation in education between parents and children in most countries is high, with correlations varying between 0.30 and 0.50 . The intergenerational persistence is also high for other outcomes and traits such as income, cognitive ability, being on welfare, etc. What are the main reasons or mechanisms for this persistence in educational and other outcomes across generations?

To identify the main mechanisms for intergenerational transmission and assist in structuring further discussion in this chapter, we sketch a model inspired by Becker and Tomes (1986). However, first, let us briefly review the main channels for transmission in a more descriptive way. The educational choices of children may be conditioned by several factors that may generate intergenerational correlations in education and therefore influence the overall intergenerational correlation in education:

1) Parents' educational choices may directly affect their children's choice to enter and complete higher education; parents' human capital raises the marginal productivity of children’s education.

2) Parents may pass on unobserved genetic cognitive abilities along with other genetic traits. 
3) Families' cultural backgrounds, including unobserved factors such as risk preferences, time preferences, and parenting skills, may affect children’s choices.

4) Endowments, such as wealth or financial resources in general, may be passed on and give rise to transfers or borrowing constraints.

5) Public resources and more general public investments may directly affect or interact with parents' education and choices.

These are all broad mechanisms that have different implications for economic policies. Some of these channels can be affected by economic policies, whereas others cannot, and much emphasis has been placed on this distinction lately. The economics literature focuses on the role of parental education as the causal effect; thus, the role of human capital investments is central. However, if the correlation in education across generations is driven by a difference in inherited cognitive abilities, there is less room for economic policies, such as investments in expanding the education system. On the other hand, health policies targeting children at an early stage may be a promising approach to eliminating factors generated by genetics. Yet again, if financial constraints are the obstacle preventing children from poor economic or cultural backgrounds from reaping the economic and nonpecuniary gains from education, then subsidies to attend university or even easier access to high school and university will weaken the intergenerational transmission of education.

A small sketch of a model in line with Becker and Tomes (1986), Caucutt and Lochner (2008), Checchi (2006, ch. 7) and Lochner (2009) will be helpful in identifying more carefully these different channels of persistence. The starting point is an 
overlapping-generations model, where parents are interested in developing their own current consumption and their offspring's human capital by investing in their schooling. In addition, parents may borrow or save in the form of debts or bequests for their children. Thus, parents may transfer resources to the next generation through bequests. In line with the informal discussion of mechanisms for transmission of schooling over generations, let the production function for a child's human capital, $\mathrm{H}^{\mathrm{c}}$, be:

$$
H^{c}=f\left(H^{p}, A^{c}, S^{c}\right),
$$

where $H^{p}$ is parental human capital, $A^{c}$ is the child's ability endowment that the child is born with and $S^{c}$ is the years of schooling. It is important to note that we assume that the abilities of parents and children are correlated, and that parents' human capital and the child's ability both increase the productivity of going to school:

$$
\partial^{2} f / \partial S^{c} \partial H^{p} \geq 0 ; \partial^{2} f / \partial S^{c} \partial A^{c} \geq 0 .
$$

Given these assumptions about the interaction effects in the offspring's human capital production, the implications for parental investments are as follows: 1) given investment at any level, a child produces more human capital if his or her parents' schooling is higher or the child's ability is higher; and 2) more able children with more educated parents invest more in schooling. Hence, this assumes that parents' education has a direct effect on their children's productivity of investing and thus on how much children invest in human capital. For instance, expanding the parents’ education levels through education 
reforms will have a spillover effect on their children’s education levels. Note that Becker and Tomes (1986) assume that $d f / d H^{p}=0$.

The optimization problem, where parents allocate resources to their current consumption, $C^{p}$, and to their offspring's utility in terms of investments in human capital and bequests $\left(W^{c}\right)$, is as follows:

$$
\begin{aligned}
& \frac{\operatorname{MAX} U}{W^{p}, H^{c}}=\left[U\left(C^{p}\right)+\alpha V\left(H^{c}, W^{c}\right)\right] \text { s.t. } \\
& W^{c}=(1+r)\left(W^{p}+H^{p}-C^{p}-\gamma S^{c}\right) \geq-\bar{X} \quad H^{c}=f\left(H^{c}, A^{c}, S^{c}\right) .
\end{aligned}
$$

The optimal solution for an unconstrained family is to invest in the offspring's schooling up to the point where the marginal value of the investment is equalized across generations. Where parents are not constrained by—and children's human capital investment does not depend on-parental wealth or earnings, there are two reasons or mechanisms for a positive correlation in schooling across generations:

1) abilities are correlated across generations and they raise schooling for both parents and children; and

2) parents' human capital has a direct effect on their children's schooling because it directly affects how productive the children are in terms of schooling.

Translated to the nature-nurture framework, the first channel is very mechanical and the talent in this sense comes from nature. In the Becker and Tomes (1986) model, this is the only mechanism. Because we allow for a direct effect of parents' human capital 
on the offspring's productivity in schooling, there is also another route for parental influence on the next generation's schooling.

Allowing for budget constraints, parents have to trade off their own consumption against investment in their children's consumption (Becker and Tomes, 1986). In this case, the wealth-constrained families—-which are correlated with the low-education parents—-may underinvest in their children's education. This implies that bright children from a poor, low-education background will invest too little in schooling. Families that are not wealth constrained will not underinvest. This therefore is a third channel for an observed intergenerational persistence in education, driven by the persistence among the low-education and low-income group.

A question that is connected to the effect of budget-constrained parents and that has been the focus of recent research is how parents are budget constrained. Is it the case that parents cannot afford to send their children to university because of budget limitations, or is it the case that children from low-income and -education families are not well prepared to attend university because of budget constraints impacting upon them much earlier than when they apply for university? This question is connected to the more general question of the timing of parents' investment in their children and has been the focus of many recent studies both theoretically and in empirical research (Cunha, Heckman, Lochner and Masterov, 2007; Cunha and Heckman, 2007). Therefore, not only parental investment per se but also the timing of investment is a channel for intergenerational persistence in education patterns.

As mentioned, other channels provide possible explanations for the observed intergenerational correlation. As we argued in Section 2, the sibling correlations are large 
and intergenerational correlation is only a fraction of the total effect of family background. One important part of interhousehold differences could be preferences for patience and risk aversion, which also affect schooling decisions for both parents and children (see Becker and Mulligan, 1997).

Further, a broader set of cultural influences on parents may be important and may be transferred to children. For instance, the fact that parents with higher education may be more aware of the value of the pecuniary and nonpecuniary advantages of education may mean that they put more pressure on their children to achieve more, or that they simply provide this necessary information to their children. Another example is that parenting skills more broadly that are obviously not genetic may be inherited within families across generations. A third example is that more educated parents are more aware of quality differences in primary and secondary schools, and may be more informed when choosing an area in which to live. This choice obviously is also influenced by parental economic resources. This type of selection of residential areas that are correlated with school quality, and the impact on whom the families interact with as peers, may lead to segregation, which may provide advantages in preparing children for schooling later. This type of preference, as well as skills preferences, may be correlated with the parents’ education; of course, these preferences may in fact be influenced directly by education, but they may also be quite independent of education.

There may of course also be direct and indirect effects of public policy on the intergenerational relationship in education. In connection to the present model, in relation to budget constraints, parents will be affected both by the costs of schooling and by its benefits when deciding how much to invest in their children's education. Policies to 
lower the costs for university entry, for instance-which, in many countries, is a decision within the realm of local or central governments_-affect the intergenerational persistence because lower entry costs increase the probability of attending higher education. Another route by which public policy can affect the intergenerational persistence in education is through the interplay with educational choices. For instance, if more educated parents are better informed about the benefits and quality of education, and there exist different tracks or different qualities of universities, policies towards strengthening (weakening) tracking would increase (decrease) educational persistence. It is not only education policies per se that are relevant. For instance, because the timing of parental investment seems to be very important, policies connected to families are also relevant, such as preschool programs, maternity leave and other early invention policies such as "the no child left behind” program in the US. Clearly, these types of programs have the potential to prepare children better for their later educational choices, depending on the alternatives they have available. In addition, different effects are expected depending on the age of the child and on whether he or she stays at home with his or her parents or attends day care during the preschool period.

In sum, a person's educational choices depend in general on his or her unobserved abilities or talent, the parents' abilities and education, the family cultural background and preferences, family financial resources and public resources. Most of these factors exhibit intertemporal and intergenerational persistence and many of them are interrelated. A simple (and linear) version of the following equation is often used when estimating intergenerational transmission of education: 


$$
S^{c}=f\left(S^{m}, S^{f}, A^{p}, f^{p}, X^{p}\right),
$$

where a child's education, $\mathrm{S}^{\mathrm{c}}$, depends on both the mother's and the father's education, $S^{\mathrm{m}}$ and $\mathrm{S}^{\mathrm{f}}$, respectively, parent's unobserved ability inherited by the child , $\mathrm{A}^{\mathrm{c}}$, unobserved ability, parental child rearing skills as well as on unobserved preferences for risk and time, $\mathrm{f}^{\mathrm{P}}$, as well as parental observed resources such as wealth and income, $\mathrm{X}^{\mathrm{P}}$. Public policies in terms of all types of preschool and school policies that alter the relative costs of education also influence educational choices.

To a large extent, the factors that influence a person's educational choice, and thus the persistence of education across generations, will determine the structure of the rest of this chapter. We start by discussing more directly how nature and nurture affect a child's educational choices, and then provide an overview of the empirical literature from which a linear version of the child's educational choice function is estimated.

\section{How the family affects the child}

\subsection{Nature and nurture}

Parents obviously influence their children's school performance by transferring their genes to the children, but they also influence them directly them, via, for example, their parenting practices and the type of schools to which they send their children. It is common to talk about "nature" (genetic) and "nurture” (environmental transmission) as two broad categories of transmission mechanisms. Statements about the relative importance of nature and nurture are common in everyday discussions and there is a stream of research reports with such results. Although there are skeptics who doubt that 
there is much to learn from such decompositions, there seems to be a perennial interest in learning about the relative importance of transmission via nature and nurture in outcomes such as educational attainment. ${ }^{5}$

One research approach, which has its roots in quantitative genetics, uses correlations among relatives with different genetic and environmental connectedness to infer the relative importance of nature and nurture for the outcome of interest. In this section, we first describe this approach and report some of the results concerning schooling. We then continue with results from a more recent regression-based approach that has become increasingly popular in the social sciences.

Consider the following very simple model of educational attainment:

$$
S=g G+e E+u U
$$

where S denotes years of schooling, G denotes genetic factors, E denotes environmental factors that are shared between siblings, $\mathrm{U}$ denotes individual factors not shared by siblings and thus not correlated with either $\mathrm{G}$ or $\mathrm{E}$, and g, e and $\mathrm{u}$ are the corresponding factor loadings. This model is very simple with its additive structure that rules out causal interaction effects between $\mathrm{G}$ and $\mathrm{E}$. If we add the even stronger assumption that $\mathrm{G}$ and $\mathrm{E}$ are uncorrelated, we obtain the much-discussed decomposition of the variation in S into nature and nurture components. This decomposition is more transparent when S, G, E and U are all standardized to have a mean of zero and a variance of one. Then, we obtain:

\footnotetext{
${ }^{5}$ Goldberger (1979) offers a well-known and strong critique of the nature-nurture decomposition.
} 


$$
\operatorname{var}(S)=1=g^{2}+e^{2}+u^{2}
$$

With information about the schooling correlation among certain family members, it is possible to infer the components of equation (2). For example, the correlation between MZ twins, who have the same genes and are likely to share as many environmental factors as any siblings, gives us $g^{2}+e^{2}$, because for them $\operatorname{Corr}\left(G, G^{\prime}\right)=\operatorname{Corr}\left(E, E^{\prime}\right)=$ 1. For DZ twins, we can follow common genetic models and assume that half of their genes are shared, so $\operatorname{Corr}\left(G, G^{\prime}\right)=0.5$, and that their environmental influences are fully shared, giving us $\operatorname{Corr}\left(E, E^{\prime}\right)=1$, and thus $\operatorname{Corr}\left(S, S^{\prime}\right)=0.5 g^{2}+e^{2}$. These two sibling correlations therefore identify $\mathrm{g}^{2}$ and $\mathrm{e}^{2}$. A model that uses these strong assumptions is the prototypical model in much research on the influence of nature and nurture. As a matter of fact, we can now use the MZ and DZ correlations in Tables 1 and 2 to illustrate this approach. The Australian MZ and DZ estimates imply that $g^{2}=0.60, e^{2}=0.10$ and $u^{2}=0.30$, whereas the Swedish estimates imply that $g^{2}=0.42, e^{2}=0.34$ and $u^{2}=0.24$.

With the same assumptions, it would be possible to identify these same components by using information on correlations among full (nontwin) siblings and half siblings who have been reared together. For full siblings, we have Corr $\left(S, S^{\prime}\right)=0.5 g^{2}+$ $e^{2}$, and for half siblings reared together, we have $\operatorname{Corr}\left(S, S^{\prime}\right)=0.25 g^{2}+e^{2}$.

In addition, it is possible to estimate $\mathrm{g}^{2}$ separately from a correlation between identical twins who have been reared in different environments if we are willing to assume that these environments are independent and that the twin siblings were separated immediately after birth. ${ }^{6}$ Such twin pairs are very rare. Even with a reasonable sample,

\footnotetext{
${ }^{6}$ Indeed, the concepts prebirth and postbirth are more appropriate because, in these studies, there is no way
} 
one could strongly doubt that the necessary assumptions would be fulfilled. In a similar fashion, $\mathrm{e}^{2}$ could be estimated using a correlation between adopted siblings who share only the same environment. Such sibling pairs are also rare and generally have not shared the same environment throughout their whole childhoods.

With information about estimates based on several sibling types, the underlying model becomes over-identified. In such cases, the typical approach is to choose the parameters that minimize the sum of squared errors between the sample moments and the fitted values of the sample moments. With estimates of more sibling types (or other family relationships), it is also possible to extend the model and make it more realistic.

Björklund, Jäntti and Solon (2005) use nine different sibling types: MZ twins, DZ twins, full siblings and half siblings, with all four of these types split into those siblings reared together and those reared apart, and adoptive siblings. All of the sibling types are derived from Swedish register data, including a representative sample of same-sex twins with zygosity information. Their outcome variable is long-run earnings, but the results are likely to be relevant for schooling as well. With nine sibling types at their disposal, they are able to test the assumptions of the underlying prototypical model; it was clearly rejected by the data. Of the more general models that impose weaker assumptions, they first show that the data did not reject the assumption of common genetic models that full biological siblings share $50 \%$ of their genes and half siblings share $25 \%$. More surprisingly, when they allowed $G$ and E to be correlated, and thus treated Corr (G, E) as a parameter to be estimated, they found that this parameter was insignificant and did not lead to a nonrejected model. It is not possible to allocate such a variance component to 
either nature or nurture because it belongs to both. The only model not rejected by the data was one that allowed a different degree of shared environments for reared-together MZ and DZ twins and allowed the environments of siblings reared apart to be correlated. Using that model, Björklund, Jäntti and Solon estimate that $\mathrm{g}^{2}=0.20$ and $\mathrm{e}^{2}=0.16$ for brothers, whereas for sisters, the estimates were $\mathrm{g}^{2}=0.13$ and $\mathrm{e}^{2}=0.18$, suggesting that approximately equal importance should be assigned to genetic factors and shared environments as determinants of earnings. By contrast, the prototypical model yielded estimates of $\mathrm{g}^{2}=0.28$ and $\mathrm{e}^{2}=0.04$ for brothers and $\mathrm{g}^{2}=0.25$ and $\mathrm{e}^{2}=0.01$ for sisters. In recent work, Cesarini (2010) follows and extends this approach with Swedish register data for men. He estimates variance components of alternative models using seven sibling types; he excludes MZ- and DZ-twins reared apart, which in Björklund, Jäntti and Solon had low weights due to small sample size. From our point of view, it is especially relevant that Cesarini not only considers income as outcome variable but also years of schooling, cognitive skills and non-cognitive skills. For income, his results are quite similar to the previous ones, namely that $\mathrm{g}^{2}$ clearly dominates $\mathrm{e}^{2}$ with the prototypical model but that the two components are more similar when more flexible assumptions are made about the degree of shared of environment. For years of schooling, however, the results are different in two respects. First, the correlations are generally stronger, suggesting a more important role of family background for schooling than for income. Second, all models suggest that nature is more important than nurture; for example a model in which the degree of genetic relatedness is estimated without any restrictions and nontwins reared together are allowed to share less environment that twins not are not constrained most models $\mathrm{g}^{2}$ is estimated to 0.49 and $\mathrm{e}^{2}$ to 0.21 . 
While Cesarini's results suggest that the genetic contribution to schooling inequality dominates the contribution of shared environment for MZ-twins (and other sibling types), our interpretation of these studies is that even the extended models rely on very strong assumptions and that the results generally are quite sensitive to these assumptions. Thus, much the results must be interpreted with great care.Another approach to examining the relative importance of nature and nurture is to start out with an intergenerational association between the educational attainment of parents and children, and make a distinction between biological parents, who transfer nature, and adoptive parents, who transfer nurture. This is a quite transparent approach, but it focuses only on the observed parental characteristics, which (as we saw in Section 2) account only for some $30 \%$ to $40 \%$ of factors shared by siblings. The variance-decomposition approach, however, focuses on factors shared by siblings, irrespective of whether they are observed factors.

In Table 5, we report estimates from this approach in recent studies by Plug (2004), Björklund, Lindahl and Plug (2006) and Sacerdote (2007). ${ }^{7}$ Each column in the table reports results from two separate regressions of own birth and adoptive children. Björklund, Lindahl and Plug use Swedish register data on adopted children and their biological and adoptive parents to estimate models with both types of parents. For fathers, they find that the coefficients for the biological father and the adoptive father are significant and of equal magnitude. For mothers, both coefficients are also positive and significant, but the one for the biological mother is larger. Strikingly, for both fathers and

\footnotetext{
${ }^{7}$ See Scarr and Weinberg (1978), Sacerdote (2002) and Plug and Vijverberg (2003) for seminal contributions and Björklund, Jäntti and Solon (2007) for more analysis along these lines.
} 
mothers, the sum of the two coefficients is very close to the coefficient in regressions on families with own birth children.

In this comparison among parental variables, all are positive and generally significant and of about the same magnitude. Björklund, Lindahl and Plug (2006) also include interactions between adoptive and biological parents. The interactions are positive and significantly different from zero for mothers, but close to zero with very small standard errors for fathers. In this regression framework, as well as in the variancedecomposition framework discussed above, interaction effects imply that a straightforward decomposition into "nature” and "nurture” is not possible. Sacerdote's (2007) results are relevant here. When he estimates separate intergenerational income coefficients for adopted and biological children in the same families, he obtains coefficients for adopted children that are about two-thirds of those for biological children.

What overall conclusions can be drawn from this research? Nature (or prebirth) factors and nurture (or postbirth) factors each account for at least one-third of the family associations. This holds both when the family background's share is assessed using sibling correlations and when it is measured using regression coefficients for biological and rearing parents' income or education. Therefore, any comprehensive theory for the impact of family background must incorporate both nature and nurture components. Any theory that focuses on only one of these will be incomplete. The conclusion about the substantive importance of both types of factors is reinforced by the possible presence of interactions between nature and nurture. It does not follow that policies can only affect the part of the family correlation that is associated with nurture. Most likely, different 
types of policies are needed to affect different sources of the family background impacts. Identifying these policies requires a quite different type of analysis.

\subsection{The causal effect of parental education levels on their offspring}

There is now a growing literature attempting to identify the causal effect of parental education on children's education, as well as on other adult outcomes. The question is whether higher parental education causally affects their children's own education, or whether there are other confounding factors, such as genetic or other prebirth effects that create the strong cross-sectional relationship between parents and children. Basically, this very recent literature estimates a linear version of equation (11), where the focus is on using different natural experiments to tease out the causal effect of parental education, as opposed to other factors, in explaining the offspring's education. More precisely, this literature examines what the effect of parental education per se is in explaining children's schooling. Here, we summarize and discuss the recent approaches and results in this literature.

The recent literature has taken three approaches to identifying the intergenerational transmission of human capital by examining twins as parents, adoptees and instrumental variables. ${ }^{8}$ To help interpret the results from these three approaches, first we present the framework being used and then point out what the differences in approach may tell us about what is measured. We then summarize the results.

\footnotetext{
${ }^{8}$ There is also a small literature on the structural estimation of the intergenerational transmission of education; see Belzil and Hansen (2003).
} 


\subsubsection{Framework}

We start by presenting a generic reduced form intergenerational mobility model (see, for instance, Behrman and Rosenzweig, 2002) for educational achievement, where both parents potentially contribute to their children's outcomes. A linear version of equation (11) is used where we are more explicit how split the inheritable unobserved factors in two parts :

$S^{c}=\delta_{1} S^{m}+\delta_{2} S^{f}+\Gamma_{1} h^{m}+\lambda_{1} f^{m}+\Gamma_{2} h^{m f}+\lambda_{12} f^{f}+\rho X+\varepsilon^{c}$

Here, $S^{c}$ is the educational achievement of child and $S^{m}$ and $S^{f}$ represent the education of the mother and the father, respectively. The $h$ s are the unobserved heritable endowments of both parents, whereas the $f$ s represent the unobserved talents for child-rearing and parental skills. $\mathrm{X}$ is a vector of observed family-specific variables, such as family income, age of mother at birth, grandparents' education (to capture, for instance, inborn childrearing skills of the parents), as well as child-specific demographic variables such as gender and year of birth. The $\delta_{i}$ parameters reflect the effects of parental schooling on children's schooling, conditioned on other observed family characteristics (from X), unobserved child-rearing abilities and heritable endowments. However, in general, we cannot assume that the parents' schooling levels are independent of heritable endowments, child-rearing endowments and assortative mating. Indeed, we would expect that parents' education is positively correlated with heritable endowments, child-rearing endowments and assortative mating. Note also the difference here between the descriptive intergenerational correlations reported in Section 2 capture the total 
correlation between offspring's and parents' education, the causal effect as well as the impact of the omitted variables that are specified in (1). Three different strategies are used in the literature to identify the causal effect of parental education on children's education. We now turn to a discussion of these strategies.

\subsubsection{Adopted children}

Using adopted children provides an experiment based on children who do not grow up with their biological parents and adds the assumption that the children are randomly allocated to their nonbiological parents. Thus, within the sample of rearing parents and adopted children, there is no association between unobservable heritable endowments of parents and their adopted children $\left(\Gamma_{1}=\Gamma_{2}=0\right)$. Thus, equation (1) is reduced to:

$$
S^{c}=\delta_{1} S^{m}+\delta_{2} S^{f}++\lambda_{1} f^{m}+\lambda_{12} f^{f}+\rho X+\varepsilon^{c},
$$

where the confounding genetic effects in (1) are eliminated. Compared to equation (2), we see that the inborn child-rearing endowments for both parents remain. There are reasons to believe that these will provide an upward bias because of a positive correlation between the mother's education and child-rearing endowments, and because of assortative mating. In addition, notice that using adoptees hinges on the assumption of random allocation of children to nonbiological parents, i.e., that the parents adopting children are not a strongly selected group of parents compared with the rest of the population. Further, it is expected that the age of the adopted child matters, as does 
whether the adopted child is foreign born and or from the same country as the parents. These conditions will differ across studies.

\subsubsection{Twins as parents}

Another strategy is to use the difference in educational attainment for children born to twin mothers (or fathers) and, in that respect, assess differences between children with (at least partly) the same heritable endowments. Taking the difference between the children of twin mothers, we obtain9:

$$
\Delta S^{c}=\delta_{1} \Delta S^{m}+\delta_{2} \Delta S^{f}+\rho \Delta X+\Delta \varepsilon^{c}
$$

This equation can be estimated separately for twin fathers and twin mothers. In the case of MZ twin mothers, $\Delta h^{m}=0$. More generally, the effects both of genetic factors and of unobserved child-rearing endowments shared by twin sisters are eliminated by studying the difference between cousins with twin mothers. If fraternal twins are used instead of MZ twins, the genetic difference between the twins is likely to contribute to a nonzero correlation between differences of $h$ and $S$. This may introduce an upward bias in the estimation of $\delta_{1}$. Moreover, assortative mating may cause a correlation between the within-mothers' schooling differences and the unobserved endowments of the fathers. However, because assortative mating in education is likely to be positive, and we expect that heritable and nonheritable endowments are correlated, the inclusion of fathers'

9 This approach in economics follows the children of twins (COT) tradition in behavioral genetics (D’Onfro, 2005) 
education levels may pick up at least some of the parts of $h$ and $f$ that are not differenced out.

Several issues arise with this approach if important assumptions are not met. Because the educational choices of the twin parents have to be different in order to identify parameters using this approach, the educational choices may not be random as is assumed. In this case, with unobserved heterogeneity between twins even if $\Delta h^{m}=0$, it is commonly argued that family (grandparent) fixed effects estimates, such as those in equation (16), do not necessarily reduce the bias as long as some nonrandom unobserved heterogeneity remains (Griliches, 1979; Bound and Solon, 1999). For instance, this nonrandomness in schooling choice for twins could come about through differences in $f$ in our model if twins are treated differently by parents or if they are different by birth. For instance, Behrman and Rosenzweig (2004) argue that this type of heterogeneity can be explained by birth weight differences within MZ twins in the US; this is also supported by Black, Devereux and Salvanes (2007a) using MZ twins for Norway. Measurement error introduces another possible problem when it comes to estimating a within-family fixed effects model. If misrepresentation of parental education is a serious problem in our analysis, it is well known that the attenuation bias from the classical measurement error in the variable on the right-hand side of the equation is inflated in fixed effects estimators, simply because noise constitutes a larger share of the observed schooling variation. ${ }^{10}$ In fact, if the measurement error is corrected for by using an IV estimator for differences between twins, the ability bias in the IV may be exacerbated, as discussed thoroughly in Neumark (1999).

\footnotetext{
${ }^{10}$ If classical measurement errors are positively correlated within families (i.e., between siblings), the attenuation bias using fixed effects may not exceed that from OLS.
} 


\subsubsection{Natural experiments}

The third approach to identifying causal effects is to use exogenous variations in parents' education as a natural experiment. For the case of the impact of mother's education we have:

$$
\begin{aligned}
& S^{m}=\varphi Z+\phi X+v, \\
& S^{c}=\delta_{1} S^{m}+\phi X+\varepsilon,
\end{aligned}
$$

where $\mathrm{Z}$ is the instrument used to identify the mother's education. Thus, we are attempting to isolate the pure effect of the mother's education on the child's education and control for unobserved factors. In the literature, mandatory education reforms for mothers and/or fathers have been used. Again, the same issue of assortative mating holds. In addition, the group most influenced by the mandatory school reforms that have extended education, is most likely at the bottom of the educational distribution. Most notably this implies that the results must be interpreted as local average treatment effects.

\subsubsection{Discussion of results}

In the light of the general framework, we now present the more recent contributions for the three different specifications. In addition, we present results from two papers where two or three different approaches are used with the same data set, in order to assess differences across methodologies. In addition to inherent differences across specifications, as we have discussed, other issues exist when comparing results on 
intergenerational persistence across studies. For instance, there are differences in the studies in terms of whether the year of birth of the children and parents are included in order to control for trends in educational attendance over time. In addition, some studies control for the grandparents' educational background in order to control as much as possible for persistence in inborn child-rearing skills. More important, though, in terms of the effect on estimated intergenerational education parameters, is whether the spouse's education is included in order to control for the effect of assortative mating in education. The thought or policy experiments being conducted influence whether the spouse's education is included. For instance, in an equation of the effect of the mother's education on the child's education where the spouse's education is included, one can obtain the answer to the question of whether the mother's education affects a child's education when assortative mating in education is controlled for. This experiment answers the question of whether it helps to increase a mother's education in order to increase a child's educational performance. If the spouse's education is not included, the experiment answers whether parental education increases a child's educational outcome, independent of whether the mechanism also operates through assortative mating. Both questions are relevant, but it is important to distinguish between them because the results sometimes differ substantially. Another issue is, of course, which data set (country and number of observations) and time period are used in the study, as there may be differences in patterns across countries or across cohorts. Finally, different educational outcomes are being used in the studies.

In Table 6, we summarize the main results by identification strategy, and indicate the data period and data source, zygosity of twins, and other characteristics of the data set 
and specifications. More specifically, we indicate in a separate column whether assortative mating was controlled for. We start by presenting the results for studies using parents who are twins, reporting separate results for mothers and fathers who are twins. We present both cross-sectional results and within-parental-twin estimates. All five studies for which we present results — two from the US using the same data set and three from different Nordic countries—show a strong persistence in education across generations, as can be seen from the cross-sectional results. The intergenerational persistence is estimated to be higher in the US than in Scandinavia, and it is also somewhat higher when a child's education is measured by his or her grades at the end of lower secondary school, compared with his or her completed education. One of the first papers to do this was Behrman and Rosenzweig (2002), who use data on pairs of identical twin parents to eliminate confounding genetic effects. Despite observing a positive correlation between the mother's education and the child's education, the authors find no effect between the mother's schooling and the child's schooling once one looks within female MZ twin pairs, thereby differencing out any genetic factors that influence children's schooling. The analogous fixed effects exercise using male MZ twin pairs gives coefficients for the father's education that are about the same size as the OLS estimates. Results that do and do not control for assortative mating are presented, and do not differ greatly for this specification. Antonovics and Goldberger (2005) question these results and suggest that the findings are somewhat sensitive to the coding and sampling of the data. As we can see from Table 1, the results do not really differ from Behrman and Rosenzweig's results; both indicate a positive effect of the father's education and no effect from the mother's education. The three papers using data from Sweden, Denmark 
and Norway do partly resemble the US studies, but there are some differences. Holmlund, Lindahl and Plug (2008), studying DZ twins for mothers and fathers, find no effect of the mother's education on child outcomes when controlling for assortative mating, but they do find a positive effect of mother's education without this control (one-fourth of the effect from the OLS results). For the twin fathers' sample, they do find an effect of father's education (about one-half of the effect of the correlation). Bingley, Christensen and Myrup Jensen (2009) studied identical twins (as well as DZ twins) from the Danish Twins registry and several outcomes, such as grade point average (GPA) at the end of lower secondary school and completed education at 30 years of age (the latter results not presented). Their results show no effect of mother's education on the GPA in ninth grade or on years of completed education (the latter effect is positive for parental cohorts born after 1945). Father's education is shown to have a significantly negative impact on children's GPAs, whereas it has a positive effect on years of education (although this is reversed for parental cohorts born after 1945, which show no effect of father's education on children's education). Further, when using DZ twins (not reported here), Bingley, Christensen and Myrup Jensen find a positive effect of mother's education on both educational outcomes (about half the size of the OLS results). Hægeland, Kirkebøen, Raaum and Salvanes (2010) use DZ twin data from Norway with GPAs at the end of lower secondary school. With the same outcome and the same cohorts, these results are directly comparable to those of Bingley et al. (2009). For mother's education, there is no effect on children's education when using within twin mothers, independent of whether spouse's education is controlled for. This result resembles the previous papers, except for Bingley et al. for DZ twins. For fathers, the effect is about one-third of the OLS results 
but is not significant. Nonlinear effects are not found to be very important in these studies. For instance, Hægeland et al. test whether their results indicating no effect of mother's schooling are the result of power couples, such as parents who are both medical doctors. They find not support for this. They do not find any support for the theory that higher educated mothers who work more have a weaker effect on their children's education. This is supported by the literature for time use data, where the international finding is that more educated mothers spend more time with their children (Guryan, Hurst and Kearney, 2008).

Dearden, Machin and Reed (1997), Sacerdote (2002) and Plug (2004) were the first studies to use (small) data sets of adoptees to control for heritable effects. They report results when estimating the impact of parental education on adoptee children's education and compare it to own birth children (or to other nonadoptee samples of parents/children). If children are randomly placed with adoptive parents, the relationship between parental education and child education cannot simply reflect genetic factors. They all find a positive coefficient for father's education for the adoptees and the coefficient falls only slightly below the cross-sectional effect for own children. Sacerdote (2002) and Plug (2004) find a strong positive effect for mother's education, although their coefficients are reduced to about one-half of the comparison groups of own children. Unfortunately, the sample sizes are quite tiny, especially for Dearden, Machin and Reed (1997) and Sacerdote (2002). Using a larger sample of Korean children adopted in the US, Sacerdote (2007) finds that the effect of mother's education on the adopted child's education remains important and is estimated to be about one-third of the effect for the comparison group. Björklund, Lindahl and Plug (2006) use Swedish adoptees 
placed in the years 1962-1966, and find a positive effect of adoptive fathers' education on their children's education, but the effect of adoptive mothers falls to between one-fifth and one-fourth of the own-children effect. The effect of mother's education becomes really small when assortative mating is controlled for. Holmlund, Lindahl and Plug (2008) use both foreign-born and Swedish-born adoptees. For the Swedish-born adoptees, they find very similar effects as in Bjørklund. Lindahl, and Plug (2006). It is notable that the effect of mother's education disappears when spouse's education is included. For foreign-born adoptees, the effect of parents' years of schooling on children's years of schooling is found to be much smaller than has been found in previous studies. When spouse's education is included, the effect is zero. The authors also test the effect using a small sample of Korean adoptees, as in Sacerdote (2007), but the sample is too small to provide any significant result. Hægeland et al. use a sample of Korean adoptees in Norway and find significant effects of mother's education, even when spouse's education is included, amounting to about one-third of the size of the comparison group. For father's education, the effect is about the same, but it vanishes when spouse's education is included. Taken together, using the large data-register-based data sets for adopted children from the Nordic countries, the effect of parental education on children's education is relatively small compared with the earlier studies from the US and UK using much smaller samples. The age at which children are adopted is found to be important in several of these studies, and Bjørklund, Lindahl and Plug (2006) find that selection is important when using information on education for both biological and adoptee parents for Swedish-born adopted children. 
The third strategy attempting to identify the causal effect of parental education on their offspring's education is the instrumental variables approach. Black, Devereux and Salvanes (2005b) focus on a mandatory school reform that took place over a 10 -year period in Norway, where the reform was adopted at different years in different municipalities. In this way, the reform had the character of a social experiment that the authors use, in addition to municipality and cohort fixed effects, to identify the causal effect of parental education on the children's education. They find a positive causal effect of the father's education and no effect of the mother's education on their offspring's educational attainment.

Chevalier (2003) and Oreopoulos, Page and Stevens (2006) use changes in compulsory schooling laws to identify the effect of parental education on children's educational outcomes. Chevalier uses a change in the compulsory schooling laws in Britain in 1957 and finds a large positive effect of a mother's education on her child's education, but no significant effect of paternal education. However, this paper suffers from the fact that the legislation was implemented nationwide; as a result, the identifying variation in parental education arises both from secular trends in education and from the one-off change in the law. Ignoring the existence of cohort effects may be a particular problem in this context, as less-educated individuals are more likely to have children while young and, therefore, in a sample of individuals with children of a certain age, older individuals are likely to have more education. Oreopoulos, Page and Stevens (2006) use compulsory schooling legislation in the US, which occurred in different states at different times, to identify the effect of parents' educational attainment on children's 
educational attainment. They find that increasing the education of either parent has a significantly negative effect on the probability that a child will repeat a grade.

Carneiro, Meghir and Parey (2007) use different instruments for the cost of schooling - for example, the distance to college in the US - to assess the effect of parental education on their children's math and reading scores, as well as grade repetition. They find a positive effect of both parents' education for their children's math and reading scores at age eight, but no effect of mother's education on children's reading scores when children were 12-14 years. They find a positive effect of a reduction in grade repetition. McNally and Maurin (2008) use the change in the qualification level required for acceptance to universities in France in 1968, which occurred as a consequence of the student revolt in May, to identify the effect of parental education on their children. They find that an increase in parental education reduced grade repetition for the children. Page (2006) uses the US GI Bill for Veterans from World War II to identify the effect of paternal education on children's education and finds a positive effect. Holmlund, Lindahl and Plug (2008) find results very much in line with Black, Devereux and Salvanes (2005a) when they use a very similar Swedish mandatory education reform that took place 10 years before the Norwegian one. The study is also consistent with the small effects found when using education reforms as an instrument for education, although Black, Devereux and Salvanes (2005a) find an effect of mother's education on attainment among sons and no effect of father's schooling.

\subsubsection{Comparison across methods}


In sum, all of the three approaches that attempt to identify the causal effect of parental education on their offspring's education find effects, although the strength of the effects differ across methodologies and countries and to some extent across . As we have seen, in general, the adoption approach measures the largest effects; up to one-half of the intergenerational correlation can be identified as causal. The twins-as-parents and IV approaches tend to yield weaker causal effects, particularly in regard to mother's education .

The recent papers by Holmlund, Lindahl and Plug (2008) and Hægeland, Kirkebøen, Raaum and Salvanes (2010) illustrate the findings across methodologies by using many complete cohorts of parents and children for Norway and Sweden and comparing methodologies across the same data sets. Devereux, Black and Salvanes (2005a) present results for the third strategy for Norway. The twins-as-parents and adoptees approaches arrive at similar results for both countries, but with differences across the methods, which are also reflected in the previous literature.

Although there is a strong intergenerational correlation in schooling in Norway, even when controlling for a rich set of family background variables, including assortative mating, the effect of mother's education on children's education disappears when using the twins-as-mothers strategy, whereas using the twins-as-fathers strategy, the father's schooling is weaker but remains important. In the Swedish case, the result of mother's schooling is still important (about one-fourth of the cross-sectional results) when assortative mating is not controlled for, but disappear when assortative mating is conditioned out. These results are also very similar for the IV-approach. When restricting the samples of adopted children, both studies find a statistically significant effect of 
mother's education, but no effect for father's education. Thus, these results are in line with the evidence from the literature that different identification strategies matter, even when holding the country and period constant. It is also expected a priori that these two strategies will provide different results because they represent two ways of controlling for inherit ability differences. The twin strategy assumes that both unobserved inherited endowments and child-rearing endowments are differenced out, whereas the adopted children approach controls only for unobserved inherited endowments. In addition, the adoptees specification may suffer from nonrandom selection since there is a tendency that adoptee parents are have higher education than in the rest of the population and other unobservables relevant for parenting skills be correlated with education and may not be controlled for.

Measuring the causal effect of education is literature which is still new, and there is need for new studies to attempt to understand the results. For instance, in general the causal effect of mother's education on children's education is much than the correlation in education. In order to attempt to understand this result, the Norwegian study using twins and adoptees tested whether the fact that mothers with a higher education work more may explain the results of no or small effects of mother's education. They find no significant effect for this. This result is supported by time use studies showing that mothers with a higher education spend more time with their children.

\subsection{Money and time as parental inputs}

As Section 2 makes clear, family background is by far the most important factor explaining children's educational outcomes. However, it is also relatively clear that 
parental education cannot explain all of children’s educational outcomes. On balance, parental schooling in itself is important, but other factors in the socioeconomic environment partly correlated with parental schooling are also important. The child development literature has focused on the broader effect of the childhood environment in general—including the prenatal environment for children—and outcomes for children. This literature focuses on other resources such as parental income, the timing of income and the time use of parents. The emphasis in this literature is that there is a difference in children's outcomes as a result of growing up in different families (by parental education level, etc.) because parents to invest differently in their children in terms of time and resources. Parents may invest differently across their children (gender differences/birth order) as well as in how many children they decide to have, thereby perhaps trading off quality for quantity. As these investments in time and money in children are correlated with education, they are reasons for-and will enforce-persistence in education across generations.

We provide an overview of some of this literature, focusing on particular aspects, without intending to provide a complete picture (see Almond and Currie, 2010, and Conti, Heckman and Zanolini, 2009, for recent and extensive overviews of this literature on early investment in human capital and children’s outcomes).

\subsubsection{Early learning: critical periods and dynamic complementarities}

The recent literature provides reasons to expect that the timing of parents' investment in children will have an effect on the children's adult outcomes, independent of the level of investment. First, a wealth of evidence has documented differential accumulation of 
various skills across the lifetime of children (Heckman, 2006; Knudsen, Heckman, Cameron and Shonkoff, 2006; Cunha and Heckman, 2007; Heckman and Masterov, 2007). For instance, Cunha and Heckman (2007) note the presence of critical periods for investment in the development of certain skills. They note that the improvement of IQ and the aptitude to learn a language are stronger early on in life, although humans are able to develop and improve their vocabulary into their adulthood. This means that we may expect to find heterogeneity in the effect of income across the lifetime of the child. Further, a paper by Carneiro and Heckman (2003) distinguishes between short-term and long-term credit constraints that influence optimal investment in child human capital. They argue that the short-term income constraints facing parents at the time of their child's potential enrolment in college have no significant effect on child enrolment once the longer-term constraints are controlled for. Such long-term constraints are defined broadly in terms of family background characteristics, for example the parents' education level, their age at the birth of the first child and other indicators of socioeconomic status that are fixed across the child's life. The consequence of a lifetime of binding long-term credit constraints is that, by the time the child is of college age, he or she will not have developed the prerequisite skills for attending college.

Another aspect of the timing of investment in child human capital is that of dynamic complementarity in the manifestation of income in different periods across time into child skills. In their evaluation of the US Head Start program, Currie and Thomas (1995) find that the initially positive effects of the program fade out, or reduce over time, for black children. Currie and Thomas (2000) argue that this is because the black children experienced a lower quality of postprogram education than the white children did. This 
suggests that investments across time are complementary in nature, whereby the marginal return to later (earlier) investment increases the level of early (late) investments. Further, Levy and Duncan (2000) use a family fixed approach to look at how the timing of parental income drives child education and similarly conclude that income received in the early years matters the most. This literature is rapidly developing as documented by Almond and Currie (2010) and the papers by James Heckman and co-authors, which provide recent extensive overviews of contributions and directions for new research.

\subsubsection{Family size and birth-order effects}

The economics of the family suggests that children's success in general, and in particular their schooling, depends on childhood conditions. In particular, there is a strong focus in economics on the inter- and intra-familial differences in investment in children, leading to subsequent differences in adult outcomes. These observations have resulted in a wellestablished theoretical and empirical literature on the effects of both family size and birth order.

Family size may matter for schooling achievements because there may be a tradeoff between child quantity and quality (Becker, 1964; Becker and Lewis, 1973; Becker and Tomes, 1976). This theory develops a model in which there is an interaction between quality and quantity in the budget constraint, which leads to a trade-off in the quality and quantity of children in a family. These models then predict that, with an exogenous increase in family size, there is a negative effect on child quality, as measured, for instance, by scholastic performance or other outcomes. The models assume that this effect is homogeneous across children within families. 
There are also several hypotheses in the literature about the biological, economic and psychological impacts of birth order (see Blake, 1989, for seminal work and a summary of many of the earlier studies in this field). First, siblings may not receive an equal share of resources devoted to their education. Pecuniary or time resources may differ across siblings, for instance such that parents are able to devote more time to the eldest child relative to the younger siblings (Price, 2006). In addition, for higher birthorder children, there is a greater probability that the parents will be divorced, which may affect these children's development. In addition, there may be biological differences resulting from birth order because of a differing quality of prenatal care, or differences in the behavior of expectant mothers. Further, there is a tendency for children with a higher birth order to be born to older mothers, which may lead to a difference in support in the womb. Uncertainty regarding the rewards for having an extra child may also lead to an optimal stopping rule for parents. Parents continue to have more children if the first child is a good draw and then stop when there is a less favorable draw. Psychologists have provided several additional explanations and the “confluence” model by Zajonc (1976) has been very influential in explaining the effect of birth order on IQ, which, of course, may subsequently influence schooling and earnings. This theory has two elements: 1) a person's IQ is influenced by the average family environment, for instance, the average family IQ level; and 2) older children learn more from teaching younger children than younger children gain by being taught. In this way, Zajonc (1976) explains that intelligence falls with an increase in family size and that IQ falls off for the higher birthorder children. 
The empirical literature that tests the hypothesis of whether there is a negative effect on adult outcomes of growing up in a large rather than a small family tends to find large negative associations, even controlling for socioeconomic factors (. However, the challenge is that family size may be endogenous and related to other unobserved parental characteristics affecting children's outcomes. In addition, birth order may confound family size. There are a couple of approaches to developing instruments for family size. A suggestion by Rosenzweig and Wolpin (1980) is to use twin births as compared to singletons. Alternatively, the sex composition of children may be used because it is well documented that parents have strong preferences for variety and thus are more likely to have another child at any parity if the previous children are all the same sex (Angrist and Evans, 1998).

The results in this literature when controlling for birth order and instrumenting for family size is that the negative effect of family size on schooling and labor market outcomes disappears, although there is a strong cross-sectional association between children’s outcomes and family size (Black, Devereux and Salvanes, 2005a). This finding for Norway has been supported by several subsequent studies for different countries and several outcomes (Angrist, Lavy and Schlosser, 2006; Cáceres-Delpiano, 2006; Conley and Glauber, 2006).

Testing for birth-order effects is also very challenging.. Family size has to be controlled for because children with higher birth order are more likely to be born into larger families. Because higher rank children are more likely to be born in later years, Blake stresses the need to control for cohort effects. In addition, parent cohort effects have to be conditioned out because higher rank children are more likely to have older 
parents at birth. Finally, because parents differ across families, parental characteristics have to be controlled for. Thus, it is necessary to have multiple cohorts for each birth order so that one can control for cohort effects. Full fertility histories are also required so that one can control for the mother's age at each birth and the mother's age at the birth of the first child. In addition, parental characteristics such as mother's skills must also be controlled for, as they may also be correlated with birth order, conditional on the child and mother cohort.

The empirical literature tends to find negative effects of birth order: higher order siblings perform worse than older siblings on a set of outcome variables. Some of the earlier studies, such as Behrman and Taubman (1986), find small negative effects, whereas Hanushek (1992) finds a U-shape in outcomes for black children from large families. These studies use small samples and could not include parental and children cohort effects or a full set of family size indicators. More recent papers using large data sets that were able to properly control of all these variables find significant and quite large negative effects on children's education, IQ and other outcomes (Black, Devereux and Salvanes, 2005a, 2007b).

\section{What education policy can do at different stages of the educational career: lessons from research on reforms}

Up to this point, we have stressed the literature focusing on the effect of parents' choices on children's educational outcomes: the choices regarding the quality and quantity of family resources or inputs devoted to children, and the effect of inherited capabilities. In 
addition, we made the distinction between parental choices and choices made by children, given the opportunities provided by parents. In this section, we focus on the different policy instruments that the government can use to set the general environment for parents' and children's decisions. Clearly, these policies or interventions may reduce the intergenerational persistence through economic policies affecting low socioeconomic status (SES) children. More precisely, we give an overview of the results with regard to family policies and education policies that affect parents' resource use or inputs into the family production function, which provide the environment for children's educational choices.

One route by which public policy can affect intergenerational persistence in education is through the interplay with educational choices. For instance, if more highly educated parents are better informed about the benefits of education and the quality of education, and there exist different tracks or different qualities of universities, policies that strengthen (weaken) tracking would increase (decrease) educational persistence. It is not only education policies per se that are relevant. For instance, because the timing of parental investment appears to be very important, family-related policies are also highly relevant, such as preschool programs, maternity leave policies and other early invention policies, for example, the Head Start and Perry Preschool programs in the US. Clearly, these types of programs have the potential to prepare children better for later school choices, depending on the alternatives that are available to these children. ${ }^{11}$ In addition, depending on the age of the child, different effects are expected depending on whether the child stays at home with his or her parents or attends day care before he or she

\footnotetext{
${ }^{11}$ This literature is only briefly mentioned here because it has been recently reviewed in Almond and Currie, 2010.
} 
reaches school age. Rules for the school starting age are another example of influential family-related policies.

\subsection{Maternity leave and preschool reforms}

A recent set of papers have focused on the impact of maternity leave policies not only on women's labor supply, but also on children's short-term and long-term outcomes. More specifically, the literature on changes in maternity leave policies focuses on the effects of parents' time with very young children, which can have a positive short-term effect on health outcomes for children, and medium-term cognitive and labor market outcomes for adults. In particular, the literature attempts to condition out any income effect from maternity leave changes, and focuses on the time spent by the mother or father with the child in the first months after birth. In addition, there is a longer-standing literature that focuses on parental work and children's outcomes as a result of maternity leave policy. We also briefly discuss this latter literature (see Ruhm, 2009 for a recent overview of this literature).

The theoretical results of parental time spent with children, and how this impacts on children's short-term and long-term outcomes by reducing market-based work or increasing maternity leave periods, are ambiguous (Becker and Tomes, 1986; Blau and Hagy, 1998). On the positive side, it is expected that less work outside of home implies more time - and more quality time — spent with children and thus more investment in children's development. Longer periods away from the child may imply that both parents are less attached to the child, which may have long-term negative effects on the child. However, market-based work means increased income, leading to larger investment 
possibilities in both the short run and the long run. There are also potential gains or costs for the mother. Mandatory job-protected maternity leave, leading to a continuity of employment, may increase women's earnings and increase gender equality. However, staying out of the workforce may also harm mothers’ present job roles and their earnings prospects because of a loss of human capital while taking care of children.

Given the ambiguous predictions from theory, the literature on the effect on children's short-term outcomes of parental work and of maternity leave is not conclusive. There is a literature on mother's employment on children's outcomes and a more specific literature on the effect of maternity leave policies as an exogenous variation to maternity employment, which thus impacts on children's outcomes. The results are inconclusive and they propose that more research and better methods of identification are needed to establish the causal effects of maternal employment and childcare use on children's outcomes (see Bernal and Keane, 2006, for an overview). However, on balance, positive effects are found from spending more time with children in terms of breastfeeding benefits, improved child health, reduced behavioral problems and child mortality and improved cognitive test scores (Baum, 2003, Berger, Hill, and Waldfogel, 2005, Ruhm, 2000, 2004). Papers focusing on the effect of increasing parental leave on children's outcomes are rare. Several studies focus on short-term outcomes for children. Tanaka (2005) looks at variations in maternity leave across OECD countries. He finds that longer maternity leave has a small positive impact on the birth weight and mortality rates of infants. Baker and Milligan $(2008,2010)$ use variations in maternity leave legislation in Canada across provinces to establish a causal effect of maternity leave on children's outcomes. They find that there is no impact, or a very weak impact, on different measures 
of child development. Again, these studies focus on short-term outcomes of children. There are several issues in this literature concerning identifying causal effects of time spent with children, such as selection of parents working, controlling for the negative income effect of not working, etc.

Only a few recent papers have begun to examine the long-term effects of mothers' work and maternity leave and carefully identify causal effects (Dustmann and Schönberg, 2008; Carneiro, Løken and Salvanes, 2009; Liu and Nordström Skans, 2010; and Rasmussen, 2010). These papers use data from four different countries and each arrives at different answers. There may be various reasons why the results differ. It is important when interpreting the results to note that the reforms that are studied differ in terms of the size of the extensions of mandatory education and also in terms of the timing of the extensions in the baby's life. Thus, the reforms were introduced under different conditions and therefore the alternatives for the children were different. More specifically, a change of maternity leave early in a child's life is more important than in a later period after birth. In addition, equally important for interpreting the results is the alternative: are there good day care centers available for the child's first year, and what are the child-rearing skills of the mother? The timing issue is connected to critical periods in development, as has been discussed. Whether breastfeeding is important is highly controversial in the medical literature and it remains an open question whether this is an important channel. Kramer and Kakuma (2004) undertakes a review of most of the papers in the medical literature and is critical of most of the papers he reviews. However, he finds support for the theory that breastfeeding appears to enhance cognitive development. For other outcomes such as health, the jury is still out. Dustmann and Schönberg (2009) 
assess outcomes such as wages and unemployment rates at the age of 23, and attendance at high track schools when children are teenagers. Rasmussen (2010) uses a maternity leave reform in Denmark and finds no effect on medium-term outcomes such as test scores at age 15 or children's dropout rates from high school. The reform she assesses took place in the mid-1980s in Denmark, when it appears that high quality day care was highly accessible. Liu and Nordstrøm Skans (2009) evaluate a reform taking place in the late 1980s in Sweden, which involved extending leave from 12 to 15 months, using test scores and grades at age 16 as outcomes. Carneiro, Løken and Salvanes (2009) evaluate a maternity leave reform that occurred in Norway on July 11977 and involved extending the fully covered maternity leave period from 12 to 18 weeks. All of these papers use regression discontinuity or IV techniques, using the reform as the exogenous variation. Only the last of these papers finds effects on children's teenage outcomes. The high school dropout rate declined by 2.7 percentage points as a result of the increase in maternity leave; for children of less educated mothers, the effect was more marked, with the dropout rate decreasing by 5.2 percentage points. In contrast to the other studies, the latter study was able to identify eligible mothers only, and the characteristics of the reform allowed the authors to isolate the effect of the increase in the mothers' time with their children from the effect of the decrease in income from staying home. This literature on maternity leave and other family policy related to time use with children is still in its infancy and, as yet, results are only indicative.

\subsection{Comprehensive school reforms and tracking}


After World War II, several comprehensive school reforms took place in Europe that may have affected the intergenerational relationship in education (see Lechinsky and Mayer, 1990, and Murtin and Viarengo, 2009, for overviews). The expansion of compulsory schooling after World War II was considered an integral part of the development of welfare states in Europe and one of its explicit goals was to enhance the equality of opportunity. In general, the two main components of these reforms consisted of an extension of the mandatory years of education, or a change in the school leaving age, and a change in the age of tracking. Basically, the reforms introduced nine mandatory years of schooling (or the school leaving age of 15 or 16), and all children were required to take the same academic track in lower secondary school. Tracking was thus postponed until the age of 15 or 16 . These types of reforms are expected to have affected intergenerational mobility in different ways. A general way of thinking about this is to consider the public investment in prolonged schooling at the lower secondary level as an early investment in human capital that is complementary to later skills that are acquired (Cunha et al., 2007). If this investment has a stronger effect on pupils with a disadvantaged background, we will expect that it may lead to a higher probability of completion of high school and university, and thus make completion of these degrees less dependent on family background. In this sense, the investment may lead to increased intergenerational mobility in education and, subsequently, in earnings (Restuccia and Urratia, 2004). One may also expect that staying longer in school will lead to a change in preferences for the value of schooling and in time preferences, leading to more investment in human capital, especially for those groups of children with less educated parents. Again, this may result in an increased university completion rate among the 
disadvantaged. Of course, it is an open question whether expansion of education in general will enhance equality of opportunity, as has been pointed out by several authors (see, for instance, Machin, 2007, and Peterson and Woessmann, 2007). However, the particular focus here is on the comprehensive school reforms. A relevant US reference is the high school reforms that took place during the decades prior to World War II (see Goldin and Katz, 2003, and Oreopoulos, 2005, for an overview of the effect of Canadian reforms).

Postponing the age of tracking may have a similar effect. ${ }^{12}$ Positive spillovers, from more able or less disadvantaged students to those who were less able or came from more disadvantaged backgrounds, may lead to higher attendance rates at high school and university by the disadvantaged (Hoxby, 2000). In addition, if ability is measured with noise, early tracking may also be bad for the disadvantaged because they may be assigned to the wrong track (Brunello and Checchi, 2006). ${ }^{13}$

Several recent papers have analyzed the impact of these comprehensive school reforms, particularly in Europe and Scandinavia, on aspects related to the persistence of education across generations. Meghir and Palme (2005) and Aakvik, Salvanes and Vaage (2010) analyze the effect on earnings and educational attainment of the comprehensive school reforms that took place in Sweden in the 1950s and Norway in the 1960s, respectively, where mandatory schooling was extended by two years and all students had to attend the same track. The reforms used in the studies were implemented as a natural experiment, with the new mandatory schools being adopted at different times in different

\footnotetext{
12 See Betts (2010) for an extensive overview of the literature.

${ }^{13}$ See Duflo, Dupas and Kremer (2008) and Guyon, Maurin and McNally (2010) for a recent analysis of changes in tracking and pupils' school performance.
} 
municipalities. Both studies find support for a weakening of the effect of family background for disadvantaged pupils with parents with low educational attainment. Meghir and Palme (2005) also found increased earnings among pupils with disadvantaged backgrounds using the same Swedish reform.14 Pekkarinen, Uusitalo and Pakkala (2009) more directly assess the effect on the persistence in income across generations using a similar reform in Finland in the 1970s, but the focus of this reform was more explicitly on reduced tracking. They find support for a significant decrease in the intergenerational income elasticity (for fathers and sons) in Finland from about 0.29 to about 0.23 . This is a quite strong effect, given that the standard result is that intergenerational income elasticity in the US and UK is about 0.40 and about 0.20 in other Nordic countries and Canada (Björklund and Jäntti, 2009). Bauer and Riphan (2006) results exploit differences in tracking across cantons in Swithzerland, also find support for later school tracking reduces persistence in persistence in schooling. Several other papers evaluate related school reforms and the effect of school systems in other countries. Malamud and Pop-Eleches (2008) evaluate the effect of a 1973 Romanian reform that was similar to the Finnish reforms, and focus on the effect on low SES families. They do not find any effect for these groups on university degree completion, although more students from the low SES groups became eligible to undertake university courses. The reason the reform did not result in higher attendance rates at the universities was that new openings at the university level were not established. Dustmann (2004) finds a strong connection between parental background and the choice of children's secondary track in Germany, which strongly affected subsequent

14 However, Nielsen, Sørensen and Taber (2010) only find weak effects of college subsidies on college attendance in Denmark. 
educational achievements and contributed to the low intergenerational mobility in education in Germany.

\section{Conclusions}

There is no doubt that, in recent years, the analysis of intergenerational mobility and the role of family background has become a very active research field in economics. This is not surprising because this analysis investigates issues of great scientific and policy interest, such as inequality of opportunity and child development. Recent research has also been spurred by the availability of new data; in some countries, household surveys have matured to cover more than one generation and researchers have been fortunate enough to obtain access to population-wide data sets based on administrative register information. Our survey has not done full justice to what economists have done in this field, and even less to what has been done in other fields such as psychology and sociology. In our view, the new literature has provided a number of important insights and revealed useful research strategies for the future. However, the literature has also identified many gaps in our current knowledge about the role of family background in forming human capital accumulation in the next generation.

From an inequality-of-opportunity point of view, it is common to consider family background as a broad set of factors that the individual has not chosen him or herself and thus cannot be held accountable for in a normative sense. Thus, we want to gauge the overall importance of such factors. For this purpose, we started out by presenting sibling correlations in years of schooling. What makes such correlations particularly useful as 
omnibus measures of the role of family background is that they can be interpreted as the fraction of total inequality that can be attributed to factors shared by siblings. Our survey of sibling correlation estimates suggests that, in most modern societies, these fractions are in the range of $40 \%$ to $60 \%$. Yet, these numbers represent lower bound estimates of the importance of family background because they do not take into account factors that are not shared by siblings. For example, the recent research that we discussed has shown that birth-order effects are more important than previously believed.

These numbers are nontrivial from an inequality-of-opportunity point of view. Thus, we want to know what underlies these numbers. To learn about this, recent research mainly offers analyses of intergenerational relationships between parental education and offspring's education (or income, in a related literature that we touch upon in our survey). These relationships, however, account for only about a third of what siblings have in common; the rest of the family component shared by siblings must be attributed to factors that are uncorrelated with parents' observed human capital. This result identifies one major gap in the literature, namely the factors shared by siblings that are uncorrelated with parents' education. These factors might represent unobserved parental skills and, from an inequality-of-opportunity point of view, it does not matter whether parental resources are observed. However, instead, they may mainly represent interaction among the siblings, with considerable between-family variations in effort, which in turn may not violate norms about equality of opportunity.

The analyses of intergenerational associations have provided more insights than simply providing information about the magnitude of the descriptive correlations. A sequence of recent studies have used novel methods and data to determine how much of 
the intergenerational correlations are causal, in the sense that a policy intervention that raises the education of one generation has an impact on the next generation. The conclusion that follows from our scrutiny of this literature is that, at most, half of the descriptive correlations can be considered as causal effects. This brings us even further away from the previously cited figure that $40-60 \%$ of the overall variation can be attributed to common family factors. One might conclude that these causal effects are small from an inequality-of-opportunity point of view. However, from a childdevelopment perspective they might be considerable. Whether effects are small or large from such a perspective depends on the costs to achieve the specific education reform that is considered. Because the research suggests positive effects for children, there is one more benefit to consider in the social cost-benefit analysis of education reforms.

We have also examined some recent research on the relative importance of nature and nurture (or prebirth and postbirth factors). One strand of research has attempted to decompose the broad set of factors shared by siblings, whereas another strand has examined the more narrow intergenerational associations by means of a regression approach, which compares the relative magnitude of coefficients for biological and adoptive parents. Our examination stressed that the models using sibling types in particular rely on very strong assumptions that call for much caution in interpreting the conclusions. Nevertheless, the common conclusion from both approaches is that both nature and nurture are important and it is hard to find support for the view that one is particularly more important than the other. Thus, a comprehensive model of the role of family background should incorporate both early effects and effects that are accumulated throughout childhood. 
In addition, we have stressed a recent wave of studies on the impact of policy reforms on intergenerational relationships and on outcomes for children with different socioeconomic backgrounds. Typically, the studies in this genre exploit large data sets from a specific country as well as variations across regions, cohorts and/or groups in exposure to the reform.. We consider this research to be important because it addresses explicit policy questions and has a compelling research design. A common finding is that postponement of tracking until children are older has the potential to substantially reduce the intergenerational correlations. A critic of these studies might argue that the results are specific to one country and the period in time when the reform was implemented and, thus, that the studies do not have much external validity. While this is a valid argument, when the number of studies becomes larger and covers longer periods and more countries, it becomes possible to generalize the results.

However, it is striking that, to the best of our knowledge, no reform study has yet examined the impact of the broader set of factors shared by siblings. Instead, these studies have focused entirely on the intergenerational relationships. Thus, there is room for much future research along these lines. Such research would also assist the profession to improve upon the theoretical models that dominate the field today. 


\section{References}

Aakvik, Arild, Kjell G. Salvanes and Kjell Vaage. 2010. "Measuring Heterogeneity in the Returns to Education using an Education Reform”. European Economic Review, 54, 483-500.

Almond, Douglas and Janet Currie. 2010. "Human Capital Development before Age Five”. Forthcoming Handbook of Labor Economics.

Angrist, Joshua D. and William N. Evans. 1998. “Children and Their Parents’ Labor Supply: Evidence from Exogenous Variation in Family Size”. American Economic Review, 88(3), 450-477.

Angrist, Joshua D., Victor Lavy and Analia Schlosser. 2006. "Multiple Experiments for the Causal Link between the Quantity and Quality of Children”, MIT Working Paper 06-26.

Antonovics, Kate L. and Arthur S. Goldberger. 2005. "Do Educated Women Make Bad Mothers? Twin Studies and the Intergenerational Transmission of Human Capital”. American Economic Review, 95(5), 1738-1744.

Atkeson, A. and Robert E. Lucas. 1992. “On Efficient Distribution with Private Information”. Review of Economic Studies, 59, 427-453.

Ashenfelter, Orley and Cecilia Rouse. 1998. "Income, Schooling, and Ability: Evidence from a New Sample of Identical Twins”. The Quarterly Journal of Economics ?, 253-284.

Baker, Michael and Kevin S. Milligan. 2008. “Maternal Employment, Breastfeeding, and Health: Evidence from Maternity Leave Mandates”. Journal of Health Economics, 27(4), 871-887.

Baker, Michael and Kevin S. Milligan. 2010. “Evidence from Maternity Leave Expansion of the Impact of Maternal Care on Early Child Development”. Journal of Human Resources, 45(1), 1-32.

Baum, C. L. 2003. "Does Early Maternal Employment Harm Child Development? An Analysis of the Potential Benefits of Leave Taking”. Journal of Labor Economics, 21, 609-448. 
Bauer, Philipp C. and Regina Riphahn. 2006. “Timing of School Tracking as a Determinant of Intergenerational Transmission of Education”. Economics Letters, 91, 90-97.

Becker, Gary. 1964. Human Capital. A Theoretical and Empirical Analysis, with Special Reference to Education. NBER: Chicago.

Becker, Gary S. and H. Gregg Lewis. 1973. “On the Interaction Between the Quantity and Quality of Children”. Journal of Political Economy, 81(2), S279-S288.

Becker, Gary and Casey B. Mulligan. 1997. “The Endogenous Determination of Time Preferences”. Quarterly Journal of Economics.

Becker, Gary and Nigel Tomes. 1986. "Human Capital and the Rise and Fall of Families”. Journal of Labor Economics, 4(3, pt 2). S1-S39.

Becker, Gary S. and Nigel Tomes. 1976. “Child Endowments and the Quantity and Quality of Children” Journal of Political Economy, 84(4), S143-S162.

Behrman, Jere R. and Paul Taubman. 1986. "Birth Order, Schooling and Earnings”. Journal of Labor Economics, 4(3).

Behrman, Jere, R. 1997. “Mothers’ Schooling and Child Education: A Survey”. PIER Working Paper 97-025.

Behrman, Jere R. and Mark R. Rosenzweig. 2002. “Does Increasing Women’s Schooling Raise the Schooling of the Next Generation?” American Economic Review, 91(1), 323-334.

Behrman, Jere R. and Mark R. Rosenzweig. 2004. "Returns to Birth Weight”. Review of Economics and Statistics, 86(2), 586-601.

Behrman, Jere R. and Paul Taubman. 1989. "Is Schooling Mostly in the Genes? NatureNurture Decomposition with Data on Relatives”. Journal of Political Economy, 97(6), 1425-1446.

Belzil, Christian and Jørgen Hansen. 2003. "Structural Estimates of the Intergenerational Education Correlation”. Journal of Applied Econometrics, 18(6), 679-690.

Berger, L. M., J. Hill, and Jane Waldfogel. 2005. “Maternity Leave, Early Maternal Employment and Child Health and Development in the US”. Economic Journal, $115,29-47$. 
Bernal, R., and J. M. Keane. 2006. "The Effect of Maternal Employment and Child Care on Children's Cognitive Development”. Northwestern University, mimeo.

Betts, Julian. 2010. “The Economics of Tracking in Education”. Forthcoming in Eric Hanushek, Stephen Machin and Ludger Woessmann (Eds). Handbook of the Economics of Education, Vol. III.

Bingley, Paul, Kaare Christensen and Vibeke Myrup Jensen. 2009. "Parental Schooling and Child Development.: Learning From Twin Parents”. Working Paper 07:2009 The Danish National Centre for Social Research.

Björklund, Anders, Mikael Lindahl and Erik Plug. 2006. “The Origins of Intergenerational Associations: Lessons from Swedish Adoption Data”. Quarterly Journal of Economics 121(3), 999-1028.

Björklund, Anders and Markus Jäntti. 2009. “Intergenerational Income Mobility and the Role of Family Background,” in W Salverda, B Nolan and T Smeeding (eds.) Oxford Handbook of Economic Inequality, Oxford University Press.

Björklund, Anders, Markus Jäntti and Mathew Lindquist. 2009. "Family Background and Income During the Rise of the Welfare State: Brother Correlations in Income for Swedish Men Born 1932-1967”. Journal of Public Economics,93, 671-680.

Björklund, Anders, Markus Jäntti and Gary Solon (2005), ”Influences of Nature and Nurture on Earnings Variation: A Report on a Study of Sibling Types in Sweden”, in S. Bowles, H. Gintis and M. Osborne (eds.), Unequal Chances: Family Background and Economic Success. New York: Russell Sage Foundation.

Björklund, Anders, Markus Jäntti and Gary Solon (2007), ”Nature and Nurture in the Intergenerational Transmission of Socioeconomic Status: Evidence from Swedish Children and Their Biological and Rearing Parents”. Berkeley Electronic Journal of Economic Analysis and Policy (Advances) 7/2, article 4.

Black, Sandra E. and Paul J. Devereux. 2010. "Recent Developments in Intergenerational Mobility”, Forthcoming Handbook of Labor Economics.

Black, Sandra E., Paul J. Devereux and Kjell G. Salvanes. 2005a. “The More the Merrier? The Effect of Family Composition on Children's Outcomes”. The Quarterly Journal of Economics, 120(2), 669-700. 
Black, Sandra E., Paul J. Devereux and Kjell G. Salvanes. 2005b. "Why the Apple Doesn't Fall Far: Understanding Intergenerational Transmission of Human Capital”. American Economic Review, 95(1), 437-449.

Black, Sandra E., Paul J. Devereux and Kjell G. Salvanes. 2007a. "From the Cradle to the Labor Market? The Effect of Birth Weight on Adult Outcomes”. The Quarterly Journal of Economics, 122(1), 409-439.

Black, Sandra E., Paul J. Devereux, and Kjell G. Salvanes. 2007b. “Older and Wiser? Birth Order and IQ of Young Men”, NBER Working Paper \#13237.

Black, Sandra E., Paul J. Devereux and Kjell G. Salvanes. 2010. “The More the Smarter? Family size and IQ”. Journal of Human Resources, 45(1), 33-58.

Blake, Judith. 1989. Family Size and Achievement. University of California Press: Berkeley and Los Angeles.

Blanden, Jo, Paul Gregg and Lindsey MacMillan. 2010. Intergenerational Persistence in Income and Social Class: The Impact of Within-Group Inequality, mimeo.

Blau, David. M. and Alison. P. Hagy. 1998. “The Demand for Quality in Child Care”. Journal of Political Economy, 106, 104-145.

Booth, Alison L. and Hiau Joo Kee. 2009. "Birth order matters: the effect of family size on educational attainment”. Journal of Population Economics 22, 367-397.

Bound, John and Gary Solon. 1999. "Double Trouble: On the Value of Twins-Based Estimation of the Returns to Schooling”. Economics of Education Review, 18, 169-182.

Brunello, Giorgio and Daniele Checchi. 2006. "Does School Tracking Affect Equality of Opportunity? International Evidence”. IZA Discussion Paper No. 2348.

Cáceres-Delpiano, Julio. 2006. “The Impacts of Family Size on Investment in Child Quality”. Journal of Human Resources, 41(4).

Carneiro, Pedro and James Heckman. 2003. “Human Capital Policies”. In J. Heckman and A. Krueger (Eds), Inequality in America: What Role for Human Capital Policies. Cambridge: MIT Press.

Carneiro, Pedro, Costas Meghir and M. Parey. 2007. "Maternal Education, Home Environment and the Development of Children and Adolescents”. IZA Discussion Paper Series no. 3072. 
Carneiro, Pedro, Katrine Løken and Kjell G. Salvanes. 2009. “A Flying Start or No Effect? Long-Term Consequences of Time Investment in Children During Their First Year of Life”. Memo, Norwegian School of Economics.

Caucutt, Elizabeth M. and Lance J. Lochner. 2006. “Early and Late Human Capital Investment, Borrowing Constraints and the Family”. Working Paper, University of Western Ontario.

Cesarini, David. 2010, “Family Influences on Productive Skills, Human Capital and Lifecycle Income”. Mimeo.

Checchi, Daniele. 2006. The Economics of Education. Human Capital, Family Background and Inequality. Cambridge: Cambridge University Press. Chevalier, Arnaud. 2004. "Parental Education and Child's Education: A Natural Experiment”. IZA Discussion Paper.

Coleman, James. S. et al. 1966. Equality of Educational Opportunity. US GPO: Washington DC.

Conley, Dalton and Rebecca Glauber. 2006. "Parental Educational Investment and Children's Academic Risk: Estimates of the Impact of Sibship Size and Birth Order from Exogenous Variation in Fertility”. Journal of Human Resources, 41(4).

Conley, Dalton and Rebecca Glauber. 2008. “All In The Family? Family Composition, Resources, and Similarity in Socioeconomic Status”. Research in Social Stratification and Mobility, 26, 297-306.

Conti, G., James J. Heckman and A. Zanolini. 2009. “The Developmental Origins of Health: Cognition, Personality and Education”, $6^{\text {th }}$ Annual Nestle International Nutrition Symposium.

Cunha, Flavio, James J. Heckman, Lance Lochner and Dimitriv Masterov. 2007. “Interpreting the Evidence of Life Cycle Skill Formation”. In Hanushek Eric, and Finis Welch (Eds) Handbook of the Economics of Education, Vol. 1. Amsterdam: North-Holland.

Cunha, Flavio and James J. Heckman. 2007. “The Technology of Skill Formation”. American Economic Review, 97(2), 31-47. 
Currie, Janet and Duncan Thomas. 1995. “Does Head Start Make a Difference?” American Economic Review, 85(3), 341-364.

Currie, Janet and Duncan Thomas. 2000. "School Quality and the Longer-term Effects of Head Start”. Journal of Human Resources, 35(4), 755-774.

Currie, J. 2009. "Healthy, Wealthy and Wise: Socioeconomic Status, Poor Health in Childhood and Human Capital Development”. Journal of Economic Literature.

Dearden, Lorraine, Stephen Machin and Howard Reed. 1997. “Intergenerational Mobility in Britain”. Economic Journal, 107, 47-66.

D’Onofrio, B.M. 2005. “The Children of Twins Design”. In B. Everitt and D. Howell (Eds), Encyclopedia of Behavior Statistics, 256-258. New York: Wiley.

Duflo, Esther, Pascaline Dupas and Michael Kremer. 2008. "Peer Effects and the Impact of Tracking: Evidence from a Randomized Evaluation in Kenya”.

Dustmann, Christian. 2004. "Primary to Secondary School Transitions, Parental Characteristics and Career Patterns”. Oxford Economic Papers, 56, 209-230.

Dustmann, Christian and Uta Schönberg. 2008. “The Effect of Expansions in Maternity Leave Coverage on Children’s Long-Term Outcomes”. IZA DP No. 3605.

Erikson, Robert and John H. Goldthorpe. 2010. “Income and Class Mobility Between Generations in Great Britain: The Problem of Divergent Findings from the Datasets of Birth Cohort Studies”. British Journal of Sociology, forthcoming.

Goldberger, Arthur. 1979. "Heritability”. Economica, 46(184), 327-347.

Goldin, Claudia and Lawrence F. Katz. 2003. “The Origins of State-Level Differences in the Public Provision of Higher Education: 1890-1940”. In Belfield, Clive R. and Henry M. Levin (Eds), The Economics of Higher Education. Elgar Reference Collection. International Library of Critical Writings in Economics, Vol. 165. Cheltenham, UK and Northampton, 624-629. Mass.: Edward Elgar;.

Griliches, Zvi. 1979. "Sibling Models and Data in Economics: Beginnings of a Survey”. Journal of Political Economy, 87(5), S37-64.

Guryan, Jonathan, Erik Hurst and Melissa Kearney. 2008. "Parental Education and Parental Time with Children”, Journal of Economic Perspectives, 22(3), 23-46. 
Guyon, Nina, Eric Maurin and Sandra McNally. 2010. "The Effect of Tracking Students by Ability into Different Schools: a Natural Experiment”, memo, Centre for Economic Performance, London School of Economics: London.

Hanushek, Eric A.1992. “The Trade-off between Child Quantity and Quality” Journal of Political Economy, 100( 1).

Hanushek, Eric A. and Ludger Woessman. 2010. “The Economics of International Differences in Educational Achievement.” In Handbook of the Economics of Education, edited by Eric A. Hanushek, Stephen Machin and Ludger Woessman. Amsterdam: Elsevier: forthcoming.

Haveman, Robert and Barbara Wolfe. 1995. “The Determinants of Children’s Attainments: A Review of Methods and Findings”. Journal of Economic Literature 33(4), 1829-1878.

Heckman, James. 2006. "Skill Formation and the Economics of Investing in Disadvantaged Children”, Science, 312, 1900-1902.

Heckman, James and Dimitrov Masterov. 2007. "The Productivity Argument for Investing in Young Children”. NBER WP No. 13016.

Hertz Tom, Tamara Jayasundera, Patrizio Piraino, Sibel Selcuk, Nicole Smith and Alina Veraschagina. 2007. “The Inheritance of Educational Inequality: International Comparisons and Fifty-Year Trends”. The B.E. Journal of Economic Analysis and Policy (Advances), 7(2), Article 10.

Holmlund, Helena, Michael Lindahl and Erik Plug. 2008. “The Causal Effect of Parent's Schooling on Children’s Schooling: A Comparison of Estimation Methods”. IZA DP No. 3630.

Hoxby, Caroline. 2000. "Peer Effects in the Classroom: Learning from Gender and Race Variation,” NBER Working Paper No. 7867.

Hægeland, Torbjørn, Lars Kirkebøen, Oddbjørn Raaum and Kjell G. Salvanes. 2010. "Why Children of College Graduates Outperform their Schoolmates: A Study of Cousins and Adoptees”. Working Paper, Norwegian School of Economics.

Isacsson, Gunnar. 1999. "Estimates of the return to schooling in Sweden from a large sample of twins”. Labour Economics 6, 471-489. 
Jencks, Christopher and Laura Tach. 2006. "Would Equal Opportunity Mean More Mobility?” In Morgan, Grusky and Fields (Eds) Mobility and Inequality: Frontiers of Research from Sociology and Economics. Palo Alto: Stanford University Press.

Knudsen, Erik, I. James, J. Heckman, James Cameron and J. P. Shonkoff. 2006.

“Economic Neurobiological and Behavioral Perspectives on Building America’s

Future Workforce”. Proceedings of the National Academy of Sciences, 103(27), 10155-10162.

Kramer, M.S. and R. Kakuma. 2004. "The Optimal Duration of Exclusive

Breastfeeding: A Systematic Review” Advances in Experimental Medicine and Biology, 554, 65-77.

Lechinsky, A. and K. U. Mayer (Eds). 1990. The Comprehensive School Experiment

Revisited: Evidence from Western Europe. Frankfurt am Main: Verlag Peter Lang. Lindahl, L. 2008. “A Comparison of Family and Neighborhood Effects on Grades, Test Scores, Educational Attainment and Income-Evidence from Sweden”. Essay III in L. Lindahl, Family Background and Individual Achievement, dissertation no. 75, Swedish Institute for Social Research.

Liu, Qian and Skans, Oskar Nordstrom (2010) "The Duration of Paid Parental Leave and Children's Scholastic Performance," The B.E. Journal of Economic Analysis \& Policy: Vol. 10 : Iss. 1 (Contributions), Article 3.

Lochner, Lance J. 2009. “Intergenerational Transmission”. In The New Palgrave Dictionary in Economics, $2^{\text {nd }}$ Edition.

Machin, Stephen. 2007. "Education Expansion and the Intergenerational Mobility in Britain”. In Woessmann and Peterson (Eds) Schools and the Equal Opportunity Problem. The MIT Press: Cambridge.

Malamud, Ofer and Christian Pop-Eleches. 2008. School Tracking and Access to Higher Education Among Disadvantaged Groups. Discussion paper, Columbia University.

Mazumder B. 2008. "Sibling Similarities and Economic Inequality in the US”. Journal of Population Economics, 21, 685-701. 
Maurin, Eric, and Sandra McNally. 2008. "Vive la Revolution! Long-term Educational Returns of 1968 to Angry Students”, Journal of Labor Economics.

Meghir, Costas and Mårten Palme. 2005. “Education Reform, Ability and Family

Background”, American Economic Review, 95(1), 414-424.

Miller, Paul, Charles Mulwey and Nick Martin. 1995. "What Do Twins Studies Reveal

About the Economic Returns to Education? A Comparison of Australian and U.S.

Findings”. American Economic Review, 85(3), 586-599.

Murtin, Fabrice and Martina Viarengo. 2010. “The Expansion and Conveyance of

Compulsory Schooling in Western Europe: 1950-2000”. Forthcoming

Economica.

Neumark, David. 1999. "Biases in Twin Estimates of the Return to Schooling”.

Economics of Education Review, 18(2), 143-148.

Nielsen, Helan S., Troben Sørensen, and Christopher Taber. 2010.”Estimating the Effect

of Student Aid on College Enrollment: Evidence from a Government Grant Policy

Reform”, forthcoming American Economic Journal Economic Policy.

Oreopoulos, Phil. 2005. “Canadian Compulsory School Laws and their Impact on

Educational Attainment and Future Earnings”. Research Paper No. 251, Statistics

Canada.

Oreopoulos, Phil, Marianne E. Page, and Ann H. Stevens. 2006. "Does Human Capital

Transfer from Parent to Child? The Intergenerational Effects of Compulsory

Schooling”. Journal of Labor Economics, 24(4), 729-760.

Oreopoulos, Phil, and Kjell G. Salvanes. 2010. "How Large are Returns to Education?

Hint: Money isn’t Everything”. Forthcoming Journal of Economic Perspectives.

Page, Marianne E. 2006. “Father’s Education and Children’s Human Capital: Evidence

from the World War II GI Bill”. Working Paper 06-33, UC Davies.

Pekkarinen, Tuomas, Roope Uusitalo and Sari Pakkala. 2009. "School Tracking and

Intergenerational Income Mobility: Evidence from the Finnish Comprehensive

School Reform”. Forthcoming Journal of Public Economics, 93, 965-973.

Peterson, Paul E. and Ludger Woessmann. 2007. "Introduction: Schools and the Equal Opportunity Problem”. In Woessmann and Peterson (Eds) Schools and the Equal Opportunity Problem. The MIT Press: Cambridge. 
Phelan, Christopher. 2006. “Opportunity and Social Mobility”. Review of Economic Studies, 73, 487-504.

Plug, Erik. 2004. “Estimating the Effect of Mother's Schooling on Children’s Schooling Using a Sample of Adoptees”. American Economic Review, 94(1), 358-368.

Plug, Erik, and Wim Vijverberg. 2003. “Schooling, Family Background and Adoption: Is it Nature or Nurture”. Journal of Political Economy, 11(3), 611-641.

Price, Joseph.2008. “Quality Time: The Effect of Birth Order” Journal of Human Resources, 43(1), 240-265.

Raaum, Oddbjørn, Erik Ø. Sørensen and Kjell G. Salvanes. 2006. “The Neighborhood Is Not What It Used To Be”. The Economic Journal, 116(1), 278-300.

Rasmussen, Astrid Wurtz. 2010. “Increasing the Length of Parents’ Birth-Related Leave: The Effect on Children’s Long-Term Educational Outcomes”. Labor Economics, 17(1), 91-100.

Restuccia, Diego and Carlos Urratia. 2002. "Intergenerational PErsistance of Earnings: The Role of Early and College Education”, memo, University of Toronto.

Roemer, John E. 1998. Equality of Opportunity. Cambridge, MA: Harvard University Press.

1980. “Testing the Quantity-Quality Fertility Model: The Use of Twins as a Natural Experiment”, Econometrica, 48(1), 227-240.

Ruhm, Christopher J. 2000. “Parental Leave and Child Health” Journal of Health Economics, 19, 931-960.

Ruhm, Christopher J. 2004. "Parental Employment and Child Cognitive Development”. Journal of Human Resources, 39, 155-192.

Ruhm, Christopher. 2009. “Maternal Employment and Child Development”. In R. Russel Crane and E. Jeffrey Hill (Eds.). Handbook of Families and Work: Interdisciplinary Perspectives. Lanham: University Press of AmericaSacerdote, Bruce. 2002. “The Nature and Nurture of Economic Outcomes”. American Economic Review, 92(2), 344-348.

Sacerdote, Bruce. 2007. "How Large are the Effects from Changes in Family Environment? A Study of Korean American Adoptees”. Quarterly Journal of Economics, 122(1), 119-157. 
Scarr, S. and R. Weinberg. 1978. "Educational and Occupational Achievements of Brothers and Sisters in Adoptive and Biological Related Families”. Behavioral Genetics, 24, 301-324.

Sieben, I., J. Huinink and P. M. de Graaf. 2001. "Family Background and Sibling Resemblance in Educational Attainment: Trends in the Former FRG, the Former GDR and the Netherlands”. European Sociological Review 17(4), 401-430.

Solon, Gary, Marianne Page and Greg Duncan. 2000. “Correlations between Neighboring Children in Their Subsequent Educational Attainment”. Review of Economics and Statistics, 82/3: 383-392.

Tanaka, S. 2005. "Parental Leave and Child Health Across OECD Countries”. Economic Journal, 115, 7-28.

Zajonc, R. B. 1976. “Family Configuration and Intelligence”. Science, 192, 227-236. 
Table 1. Estimates of sibling correlations in years of schooling.

\begin{tabular}{|c|c|c|c|c|c|c|}
\hline Country & Study & Sibling definition & Cohorts & Brothers & Sisters & $\begin{array}{l}\text { Mixed } \\
\text { sex }\end{array}$ \\
\hline \multirow[t]{2}{*}{ Australia } & $\begin{array}{l}\text { Miller et al. } \\
\text { (1995) }\end{array}$ & MZ twins & & & & $\begin{array}{c}0.70 \\
()\end{array}$ \\
\hline & & DZ twins & & & & $\begin{array}{c}0.40 \\
()\end{array}$ \\
\hline \multirow[t]{6}{*}{$\begin{array}{l}\text { Former West } \\
\text { Germany }\end{array}$} & $\begin{array}{l}\text { Sieben et al. } \\
\text { (2001) }\end{array}$ & $\begin{array}{l}\text { All siblings } \\
\text { reported in survey }\end{array}$ & 1919-21 & & & $\begin{array}{l}0.39 \\
\text { (n.a.) }\end{array}$ \\
\hline & & & 1929-31 & & & $\begin{array}{l}0.47 \\
\text { (n.a.) }\end{array}$ \\
\hline & & & 1939-41 & & & $\begin{array}{l}0.48 \\
\text { (n.a.) }\end{array}$ \\
\hline & & & 1949-51 & & & $\begin{array}{l}0.38 \\
\text { (n.a.) }\end{array}$ \\
\hline & & & $1954-56$ & & & $\begin{array}{l}0.40 \\
\text { (n.a.) }\end{array}$ \\
\hline & & & 1959-61 & & & $\begin{array}{l}0.38 \\
\text { (n.a.) }\end{array}$ \\
\hline \multirow[t]{4}{*}{$\begin{array}{l}\text { Former East } \\
\text { Germany }\end{array}$} & $\begin{array}{l}\text { Sieben et al. } \\
\text { (2001) }\end{array}$ & $\begin{array}{l}\text { All siblings } \\
\text { reported in survey }\end{array}$ & 1929-31 & & & $\begin{array}{l}0.30 \\
\text { (n.a.) }\end{array}$ \\
\hline & & & 1939-41 & & & $\begin{array}{l}0.25 \\
\text { (n.a.) }\end{array}$ \\
\hline & & & $1951-53$ & & & $\begin{array}{l}0.24 \\
\text { (n.a.) }\end{array}$ \\
\hline & & & 1959-61 & & & $\begin{array}{l}0.27 \\
\text { (n.a.,) }\end{array}$ \\
\hline \multirow[t]{5}{*}{ Netherlands } & $\begin{array}{l}\text { Sieben et al. } \\
\text { (2001) }\end{array}$ & $\begin{array}{l}\text { All siblings } \\
\text { reported in survey }\end{array}$ & 1925-34 & & & $\begin{array}{l}0.52 \\
\text { (n.a.) }\end{array}$ \\
\hline & & & 1935-44 & & & $\begin{array}{l}0.46 \\
\text { (n.a.) }\end{array}$ \\
\hline & & & $1945-54$ & & & $\begin{array}{l}0.47 \\
\text { (n.a.) }\end{array}$ \\
\hline & & & 1955-64 & & & $\begin{array}{l}0.45 \\
\text { (n.a.) }\end{array}$ \\
\hline & & & 1965-74 & & & $\begin{array}{l}0.41 \\
\text { (n.a.) }\end{array}$ \\
\hline \multirow[t]{2}{*}{ Norway } & $\begin{array}{l}\text { Raaum et al. } \\
\text { (2006) }\end{array}$ & $\begin{array}{l}\text { Siblings identified } \\
\text { in a census as }\end{array}$ & 1946-55 & $\begin{array}{c}0.42 \\
(0.009)\end{array}$ & $\begin{array}{c}0.46 \\
(0.006)\end{array}$ & \\
\hline & & $\begin{array}{l}\text { living with the } \\
\text { same mother }\end{array}$ & 1956-65 & $\begin{array}{c}0.42 \\
(0.008)\end{array}$ & $\begin{array}{c}0.47 \\
(0.008)\end{array}$ & \\
\hline
\end{tabular}


Table 1 continued

\begin{tabular}{|c|c|c|c|c|c|c|}
\hline \multirow[t]{3}{*}{ Norway } & $\begin{array}{l}\text { Own } \\
\text { estimates }\end{array}$ & $\begin{array}{l}\text { Siblings defined in } \\
\text { a census as living } \\
\text { with the same } \\
\text { mother }\end{array}$ & 1932-38 & $\begin{array}{c}0.40 \\
(0.008)\end{array}$ & $\begin{array}{c}0.43 \\
(0.008)\end{array}$ & $\begin{array}{c}0.40 \\
(0.007)\end{array}$ \\
\hline & & & $\begin{array}{l}1938-44 \\
1950-56\end{array}$ & $\begin{array}{c}0.41 \\
(0.008) \\
0.42 \\
(0.007)\end{array}$ & $\begin{array}{c}0.46 \\
(0.006) \\
0.48 \\
(0.01)\end{array}$ & $\begin{array}{c}0.41 \\
(0.007) \\
0.42 \\
(0.007)\end{array}$ \\
\hline & & & $\begin{array}{l}1956-62 \\
1962-68\end{array}$ & $\begin{array}{c}0.40 \\
(0.006) \\
0.40 \\
(0.007)\end{array}$ & $\begin{array}{c}0.43 \\
0.007) \\
0.43 \\
(0.008)\end{array}$ & $\begin{array}{c}0.41 \\
0.007) \\
0.40 \\
(0.007)\end{array}$ \\
\hline Sweden & $\begin{array}{l}\text { Björklund et } \\
\text { al. (2009) }\end{array}$ & $\begin{array}{l}\text { Full biological } \\
\text { brothers }\end{array}$ & $\begin{array}{l}1932-38 \\
1938-44 \\
1944-50 \\
1950-56 \\
1956-62 \\
1962-68\end{array}$ & $\begin{array}{c}0.46 \\
(0.01) \\
0.47 \\
(0.01) \\
0.47 \\
(0.01) \\
0.46 \\
(0.01) \\
0.46 \\
(0.01) \\
0.48 \\
(0.02)\end{array}$ & & \\
\hline Sweden & $\begin{array}{l}\text { Isacsson } \\
\text { (1999) }\end{array}$ & $\begin{array}{l}\text { MZ twins } \\
\text { DZ twins }\end{array}$ & & & & $\begin{array}{c}0.76 \\
\text { (n.a.) } \\
0.55 \\
\text { (n.a.) }\end{array}$ \\
\hline \multirow[t]{3}{*}{$\begin{array}{l}\text { United } \\
\text { States }\end{array}$} & $\begin{array}{l}\text { Ashenfelter } \\
\text { and Rouse } \\
\text { (1998) }\end{array}$ & MZ twins & & & & $\begin{array}{l}0.75 \\
\text { (n.a.) }\end{array}$ \\
\hline & $\begin{array}{l}\text { Conley \& } \\
\text { Glauber } \\
\text { (2008) }\end{array}$ & $\begin{array}{l}\text { Same biological } \\
\text { mother }\end{array}$ & 1958-76 & $\begin{array}{c}0.63 \\
(0.07)\end{array}$ & $\begin{array}{c}0.75 \\
(0.07)\end{array}$ & $\begin{array}{c}0.63 \\
(0.05)\end{array}$ \\
\hline & $\begin{array}{l}\text { Mazumder } \\
\text { (2008) }\end{array}$ & $\begin{array}{l}\text { Biological siblings } \\
\text { in the same } \\
\text { household }\end{array}$ & 1957-69 & $\begin{array}{c}0.62 \\
(0.02)\end{array}$ & $\begin{array}{c}0.60 \\
(0.03)\end{array}$ & $\begin{array}{c}0.60 \\
(0.01)\end{array}$ \\
\hline
\end{tabular}


Table 2. Comparisons of estimated sibling correlations among DZ twins, closely spaced full biological (nontwin) siblings and widely spaced full biological (nontwin) siblings.

\begin{tabular}{|c|c|c|c|c|c|c|}
\hline Country & Study & Cohorts & $\begin{array}{l}\text { Sibling } \\
\text { type }\end{array}$ & Brothers & Sisters & $\begin{array}{l}\text { Mixed } \\
\text { gender }\end{array}$ \\
\hline \multirow[t]{5}{*}{ Norway } & \multirow{5}{*}{$\begin{array}{l}\text { Own } \\
\text { estimates } \\
\text { based on } \\
\text { Norwegian } \\
\text { register } \\
\text { data }\end{array}$} & \multirow[t]{5}{*}{ 1946-65 } & DZ twins & $\begin{array}{l}0.54 \\
(0.01)\end{array}$ & $\begin{array}{l}0.59 \\
(0.01)\end{array}$ & $\begin{array}{l}0.49 \\
(0.01)\end{array}$ \\
\hline & & & Closely & & & \\
\hline & & & $\begin{array}{l}\text { spaced } \\
\text { nontwins }\end{array}$ & $\begin{array}{l}0.41 \\
(0.007)\end{array}$ & $\begin{array}{l}0.42 \\
(0.008)\end{array}$ & $\begin{array}{l}0.39 \\
(0.008)\end{array}$ \\
\hline & & & $\begin{array}{l}\text { Widely } \\
\text { spaced } \\
\text { nontwins }\end{array}$ & $\begin{array}{l}0.40 \\
(0.007)\end{array}$ & $\begin{array}{l}0.43 \\
(0.008)\end{array}$ & $\begin{array}{l}0.39 \\
(0.006)\end{array}$ \\
\hline & & & $\begin{array}{l}\text { All } \\
\text { siblings }\end{array}$ & $\begin{array}{l}0.40 \\
(0.007)\end{array}$ & $\begin{array}{l}0.42 \\
(0.008)\end{array}$ & $\begin{array}{l}0.39 \\
(0.006)\end{array}$ \\
\hline \multirow{3}{*}{$\begin{array}{l}\text { United } \\
\text { States }\end{array}$} & \multirow{3}{*}{$\begin{array}{l}\text { Conley \& } \\
\text { Glauber } \\
(2008)\end{array}$} & \multirow[t]{3}{*}{ 1958-76 } & Closely & & & 0.61 \\
\hline & & & $\begin{array}{l}\text { spaced } \\
\text { (twins } \\
\text { excluded) }\end{array}$ & & & $(0.05)$ \\
\hline & & & $\begin{array}{l}\text { Widely } \\
\text { spaced }\end{array}$ & & & $\begin{array}{l}0.68 \\
(0.06)\end{array}$ \\
\hline
\end{tabular}

Note: By closely spaced siblings, we mean siblings with an age spread of four years or less. 
Table 3. Estimates of intergenerational correlations in years of schooling. Standard errors in parentheses.

\begin{tabular}{lc}
\hline Country & Estimate \\
\hline \multirow{2}{*}{ Denmark } & 0.30 \\
& $(0.029)$ \\
Finland & 0.33 \\
& $(0.027)$ \\
Norway & 0.35 \\
& $(0.016)$ \\
Sweden & 0.40 \\
& $(0.024)$ \\
Netherlands & 0.36 \\
& $(0.037)$ \\
Great Britain & 0.31 \\
& $(0.035)$ \\
United States & 0.46 \\
& $(0.023)$ \\
\hline
\end{tabular}

Source: Hertz et al. (2007), Table 7. 
Table 4. Comparisons of estimated sibling (SC) and neighborhood (NBH) correlations. Standard errors in parentheses.

\begin{tabular}{|c|c|c|c|c|c|c|c|}
\hline Country & Study & Cohorts & $\begin{array}{l}\text { Sibling and } \\
\text { neighbor- } \\
\text { hood } \\
\text { definitions }\end{array}$ & $\begin{array}{l}\text { Sibling (SC) } \\
\text { and neighbor- } \\
\text { hood corre- } \\
\text { lation (NBH) }\end{array}$ & Brothers & Sisters & $\begin{array}{l}\text { Mixed } \\
\text { gender }\end{array}$ \\
\hline \multirow[t]{4}{*}{ Norway } & $\begin{array}{l}\text { Raaum } \\
\text { et al. } \\
\text { (2006) }\end{array}$ & $\begin{array}{l}1946- \\
55\end{array}$ & & SC: & $\begin{array}{c}0.42 \\
(0.01)\end{array}$ & $\begin{array}{c}0.46 \\
(0.01)\end{array}$ & \\
\hline & & & & NBH: & $\begin{array}{c}0.11 \\
(0.03)\end{array}$ & $\begin{array}{c}0.10 \\
(0.02)\end{array}$ & \\
\hline & & $\begin{array}{l}1956- \\
65\end{array}$ & & SC: & $\begin{array}{c}0.42 \\
(0.01)\end{array}$ & $\begin{array}{c}0.47 \\
(0.01)\end{array}$ & \\
\hline & & & & NBC: & $\begin{array}{c}0.06 \\
(0.01)\end{array}$ & $\begin{array}{c}0.07 \\
(0.02)\end{array}$ & \\
\hline \multirow[t]{2}{*}{ Sweden } & $\begin{array}{l}\text { Lindahl } \\
\text { (2008) }\end{array}$ & 1953 & & SC: & $\begin{array}{c}0.41 \\
(0.02)\end{array}$ & $\begin{array}{c}0.43 \\
(0.02)\end{array}$ & \\
\hline & & & & NBC: & $\begin{array}{c}0.08 \\
(0.01)\end{array}$ & $\begin{array}{c}0.05 \\
(0.01)\end{array}$ & \\
\hline \multirow[t]{2}{*}{$\begin{array}{l}\text { United } \\
\text { States }\end{array}$} & $\begin{array}{l}\text { Solon et } \\
\text { al. } \\
(2000)\end{array}$ & & & SC: & & & $\begin{array}{c}0.51 \\
(0.05)\end{array}$ \\
\hline & & & & NBC: & & & $\begin{array}{c}0.15 \\
(0.06)\end{array}$ \\
\hline
\end{tabular}


Table 5. Estimated transmission coefficients in linear models with years of schooling for offspring and parents. Standard errors within parentheses.

\begin{tabular}{|c|c|c|c|}
\hline & $\begin{array}{l}\text { Sweden: native- } \\
\text { born adoptees }\end{array}$ & $\begin{array}{l}\text { US: Korean-born } \\
\text { adoptees }\end{array}$ & $\begin{array}{l}\text { US: all adoptees in } \\
\text { Wisconsin data set }\end{array}$ \\
\hline Own birth children & (1) (2) & & \\
\hline Biological father & $\begin{array}{c}0.240 \\
(0.002)\end{array}$ & & \\
\hline Biological mother & $\begin{array}{c}0.243 \\
(0.002)\end{array}$ & $\begin{array}{c}0.315 \\
(0.038)\end{array}$ & $\begin{array}{c}0.538 \\
(0.016)\end{array}$ \\
\hline Adoptive children & & & \\
\hline Biological father & $\begin{array}{c}0.113 \\
(0.016)\end{array}$ & & \\
\hline Biological mother & $\begin{array}{c}0.132 \\
(0.017)\end{array}$ & & \\
\hline Adoptive father & $\begin{array}{c}0.114 \\
(0.013)\end{array}$ & & \\
\hline Adoptive mother & $\begin{array}{c}0.074 \\
(0.014) \\
\end{array}$ & $\begin{array}{r}0.089 \\
(0.029) \\
\end{array}$ & $\begin{array}{r}0.276 \\
(0.063) \\
\end{array}$ \\
\hline
\end{tabular}


Table 6. Summary of results: causal effect of parental education. Twins as parents, adoptees and IV studies.

\begin{tabular}{|c|c|c|c|c|c|c|c|}
\hline \multirow[t]{3}{*}{ Authors } & \multirow{3}{*}{$\begin{array}{l}\text { Data } \\
\text { I. Twins-as-parents studies }\end{array}$} & \multirow{3}{*}{$\begin{array}{l}\text { Child's } \\
\text { outcome }\end{array}$} & \multirow[t]{3}{*}{ Assortative mating } & \multicolumn{4}{|c|}{ Results } \\
\hline & & & & \multicolumn{2}{|c|}{ OLS estimates } & \multicolumn{2}{|c|}{ Difference estimator } \\
\hline & & & & $\begin{array}{l}\text { Father } \\
\text { (1) }\end{array}$ & $\begin{array}{l}\text { Mother } \\
\text { (2) }\end{array}$ & $\begin{array}{l}\text { Father } \\
\text { (3) }\end{array}$ & $\begin{array}{l}\text { Mother } \\
\text { (4) }\end{array}$ \\
\hline \multirow{4}{*}{$\begin{array}{l}\text { Behrman and } \\
\text { Rosenzweig } \\
\text { (2002) }\end{array}$} & US. Minnesota Twin Registry. MZ. 244 twin & Years of & (no) & 0.47 & 0.33 & 0.36 & -0.25 \\
\hline & $\begin{array}{l}\text { fathers and } 424 \text { twin mothers. Mean birth year } \\
\text { parents 1946. Survey from 1983-1990. }\end{array}$ & schooling & & $0.05^{* *}$ & $0.05^{* *}$ & $0.16^{* *}$ & 0.15 \\
\hline & & & (yes) & 0.33 & 0.14 & 0.34 & -0.27 \\
\hline & & & & $0.07 * *$ & $0.05^{* *}$ & $0.16^{* *}$ & 0.15 \\
\hline \multirow{4}{*}{$\begin{array}{l}\text { Antonovics and } \\
\text { Goldberger } \\
\text { (2005) }\end{array}$} & US. Minnesota Twin Register. MZ. 92 twin fathers & Years of & (no) & 0.49 & 0.28 & 0.48 & 0.03 \\
\hline & $\begin{array}{l}\text { and } 180 \text { twin mothers. Sample restricted to } 18 \text { and } \\
\text { older and not in school. Survey from 1983-1990. }\end{array}$ & schooling & & $0.09 * *$ & $0.09 * *$ & 0.16 & 0.27 \\
\hline & & & (yes) & 0.50 & 0.10 & 0.48 & -0.003 \\
\hline & & & & $N A$ & $N A$ & $N A$ & NA \\
\hline \multirow{4}{*}{$\begin{array}{l}\text { Holmlund, } \\
\text { Lindahl and Plug } \\
\text { (2008) }\end{array}$} & Sweden. Register Data. DZ. 5886 twin mothers and & Years of & (no) & 0.23 & 0.28 & 0.12 & 0.06 \\
\hline & $\begin{array}{l}4062 \text { fathers. Parents born 1935-43. Children born } \\
\text { before } 1983 \text { (at } 23 \text { or older). }\end{array}$ & schooling & & $0.001^{* *}$ & $0.002 * *$ & $0.03^{* *}$ & $0.03^{* *}$ \\
\hline & & & (yes) & 0.15 & 0.20 & 0.11 & 0.04 \\
\hline & & & & $0.002 * *$ & $0.002 * *$ & $0.03 * *$ & 0.03 \\
\hline \multirow{4}{*}{$\begin{array}{l}\text { Bingley, } \\
\text { Christensen and } \\
\text { Jensen (2009) }\end{array}$} & Denmark. Register Data. MZ. Children tested & GPA & (yes) & 0.04 & 0.07 & -0.04 & 0.00 \\
\hline & 2002-2006, aged 15-17. & & & $0.02 *$ & $0.01^{* *}$ & $0.008 * *$ & 0.008 \\
\hline & & & (yes) & 0.14 & 0.11 & 0.10 & 0.01 \\
\hline & & & & $0.02 * *$ & $0.01^{* *}$ & $0.04^{* *}$ & 0.02 \\
\hline \multirow{4}{*}{$\begin{array}{l}\text { Hægeland, } \\
\text { Kirkebøen, } \\
\text { Raaum and } \\
\text { Salvanes (2010) }\end{array}$} & Norway. Register Data. DZ. Children tested 2002- & GPA & (no) & 0.10 & 0.10 & NA & NA \\
\hline & 2006, aged $15-17$. & & & $0.001^{* *}$ & $0.001^{* *}$ & & \\
\hline & & & (yes) & 0.06 & 0.07 & 0.042 & -0.004 \\
\hline & & & & $0.001^{* *}$ & $0.001^{* *}$ & 0.022 & 0.02 \\
\hline
\end{tabular}




\begin{tabular}{|c|c|c|c|c|c|c|c|}
\hline & \multirow[t]{2}{*}{ II Adoption studies } & & & \multicolumn{2}{|c|}{$\begin{array}{l}\text { OLS estimates using own } \\
\text { birth children }\end{array}$} & \multicolumn{2}{|c|}{$\begin{array}{l}\text { OLS estimates using } \\
\text { adopted children }\end{array}$} \\
\hline & & & & Father & Mother & Father & Mother \\
\hline $\begin{array}{l}\text { Dearden, Machin } \\
\text { and Reed (1997) }\end{array}$ & $\begin{array}{l}\text { UK. National Child Development Survey.4030 own } \\
\text { birth children and } 41 \text { adopted children. Birth year of } \\
\text { child is } 1958 . \text { Measured } 1991 .\end{array}$ & $\begin{array}{l}\text { Years of } \\
\text { schooling }\end{array}$ & (no) & $\begin{array}{l}0.42 \\
0.02 * *\end{array}$ & & $\begin{array}{l}0.356 \\
0.123 * *\end{array}$ & \\
\hline Plug (2004) & $\begin{array}{l}\text { US. Wisconsin Longitudinal Surevey. } 1587 \text { own birth } \\
\text { and } 610 \text { adopted children. Birth year of mother is1940, } \\
\text { average birth year of adopted and birth child is } 1969 \\
\text { and } 1965 \text {. Measured } 1992 \text {. }\end{array}$ & $\begin{array}{l}\text { Years of } \\
\text { schooling }\end{array}$ & (yes) & $\begin{array}{l}0.39 \\
0.01^{* *} \\
0.30 \\
0.01^{* *}\end{array}$ & $\begin{array}{l}0.54 \\
0.02^{* *} \\
0.30 \\
0.02^{* *}\end{array}$ & $\begin{array}{l}0.27 \\
0.04^{* *} \\
0.23 \\
0.04^{* *}\end{array}$ & $\begin{array}{l}0.28 \\
0.10^{* *} \\
0.10 \\
0.08^{* *}\end{array}$ \\
\hline $\begin{array}{l}\text { Sacerdote } \\
(2007)\end{array}$ & $\begin{array}{l}\text { US. Holt International Children's Survey. } 1051 \text { own } \\
\text { birth and } 1256 \text { adopted children from Korea. Average } \\
\text { birth year adopted and birth child is } 1975 \text { and } 1969 . \\
\text { Measured } 2003 .\end{array}$ & $\begin{array}{l}\text { Years of } \\
\text { schooling }\end{array}$ & (no) & NA & $\begin{array}{l}0.32 \\
0.04 * *\end{array}$ & NA & $\begin{array}{l}0.09 \\
0.03^{* *}\end{array}$ \\
\hline $\begin{array}{l}\text { Björklund, } \\
\text { Lindahl and } \\
\text { Plug (2006) }\end{array}$ & $\begin{array}{l}\text { Sweden. Register data. } 148496 \text { own birth and } 7498 \\
\text { adopted children all born in Sweden. Mean birth year } \\
\text { of adoptive mother is1934. Mean birth year of child is }\end{array}$ & $\begin{array}{l}\text { Years of } \\
\text { schooling }\end{array}$ & (no) & $\begin{array}{l}0.23 \\
0.00^{* *}\end{array}$ & $\begin{array}{l}0.24 \\
0.00^{* *}\end{array}$ & $\begin{array}{l}0.13 \\
0.01 * *\end{array}$ & $\begin{array}{l}0.11 \\
0.01 * *\end{array}$ \\
\hline & 1966. Measured 1999. & & (yes) & $\begin{array}{l}0.16 \\
0.00^{* *}\end{array}$ & $\begin{array}{l}0.16 \\
0.00 * *\end{array}$ & $\begin{array}{l}0.10 \\
0.01 * *\end{array}$ & $\begin{array}{l}0.06 \\
0.01^{* *}\end{array}$ \\
\hline $\begin{array}{l}\text { Holmlund, } \\
\text { Lindahl and } \\
\text { Plug (2008) }\end{array}$ & $\begin{array}{l}\text { Sweden. Register data. Measured 1999. } 94079 \text { own } \\
\text { birth and } 2125 \text { adopted children, all born in Sweden. } \\
\text { Mean birth year of adoptive mother: } 1932 \text {. Mean birth } \\
\text { year for child: } 1964 \text {. Measured 1999. }\end{array}$ & $\begin{array}{l}\text { Years of } \\
\text { schooling }\end{array}$ & (yes) & $\begin{array}{l}0.24 \\
0.00^{* *} \\
0.17 \\
0.00^{* *}\end{array}$ & $\begin{array}{l}0.24 \\
0.00^{* *}\end{array}$ & $\begin{array}{l}0.11 \\
0.01^{* *} \\
0.09 \\
0.01^{* *}\end{array}$ & $\begin{array}{l}0.07 \\
0.01^{\text {** }} \\
0.02 \\
0.01^{\text {** }}\end{array}$ \\
\hline $\begin{array}{l}\text { Hægeland, } \\
\text { Kirkebøen, } \\
\text { Raaum and } \\
\text { Salvanes (2010) }\end{array}$ & $\begin{array}{l}\text { Norway. Register Data. } 588 \text { Korean-born adopted. } \\
\text { Less than } 12 \text { months old when adopted. Measured } \\
\text { 2002-2006. Compared to cousins. }\end{array}$ & GPA & (no) & $\begin{array}{l}0.114 \\
0.012 * *\end{array}$ & $\begin{array}{l}0.091 \\
0.012 * * \\
0.06 \\
0.012 * *\end{array}$ & $\begin{array}{l}0.04 \\
0.012 * * \\
0.02 \\
0.01\end{array}$ & $\begin{array}{l}0.031 \\
0.01^{* *} \\
0.02 \\
0.01^{\text {** }}\end{array}$ \\
\hline
\end{tabular}




\begin{tabular}{|c|c|c|c|c|c|c|c|}
\hline $\begin{array}{l}\text { Black, } \\
\text { Devereux and } \\
\text { Salvanes }\end{array}$ & $\begin{array}{l}\text { Norway. Register data. } \\
239 \text { 854/172 } 671 \text { children. Parent cohort } 1948.1958 . \\
\text { Reform 1960-1972. }\end{array}$ & $\begin{array}{l}\text { Years of } \\
\text { schooling }\end{array}$ & (no) & $\begin{array}{l}0.22 \\
0.003^{* *} \\
0.21^{1} \\
0.02^{* *}\end{array}$ & $\begin{array}{l}0.24 \\
0.003^{* *}\end{array}$ & $\begin{array}{l}0.04 \\
0.06\end{array}$ & $\begin{array}{l}0.08 \\
0.014 \\
\\
0.02 \\
0.04 * *\end{array}$ \\
\hline Chevalier (2004) & $\begin{array}{l}\text { UK. British Family Resource Surevey.12 } 593 \text { children } \\
\text { aged 16-18 living at home. Birth year of parent is } \\
\text { 1938-67. Measured 1994-2002. Reform in } 1972 .\end{array}$ & $\begin{array}{l}\text { Postcompuls. } \\
\text { School attend. }\end{array}$ & (yes) & $\begin{array}{l}0.04 \\
0.00 * *\end{array}$ & $\begin{array}{l}0.04 \\
0.00 * *\end{array}$ & $\begin{array}{l}-0.01 \\
0.06^{* *}\end{array}$ & $\begin{array}{l}-0.01 \\
0.04^{* *}\end{array}$ \\
\hline $\begin{array}{l}\text { Oreopoulos, Page } \\
\text { and Stevens } \\
(2006)\end{array}$ & $\begin{array}{l}\text { US. Integrated Public Use Microdata Series. } 711072 \\
\text { children aged 7-15 living at home. Mean birth year of } \\
\text { father is 1930. Mean birth year of child is } 1960 \text {. } \\
\text { Reforms } 1950-70 . \text { Measured 1960-80. }\end{array}$ & $\begin{array}{l}\text { Grade repetition } \\
\text { (actual-normal) }\end{array}$ & (no) & $\begin{array}{l}-0.03 \\
0.00^{* *} \\
-0.4^{1} \\
0.00^{* *}\end{array}$ & $\begin{array}{l}-0.04 \\
0.00^{* *} \\
-0.4 \\
0.00^{* *}\end{array}$ & $\begin{array}{l}-0.06 \\
0.01^{* *} \\
-0.7 \\
0.01^{* *}\end{array}$ & $\begin{array}{l}-0.05 \\
0.01^{* *} \\
-0.6 \\
0.01^{* *}\end{array}$ \\
\hline $\begin{array}{l}\text { Maurin and } \\
\text { McNally } \\
(2008)\end{array}$ & $\begin{array}{l}\text { France. Register data. French Labor Force Survey. } \\
5087 \text { children aged } 15 \text { and living at home. Birth year } \\
\text { of father is } 1945-52 \text {. University reform in } 1968 \text {. } \\
\text { Measured 1990-2001. }\end{array}$ & $\begin{array}{l}\text { Grade repetition } \\
\text { (actual-normal) }\end{array}$ & (no) & $\begin{array}{l}-0.08 \\
0.00^{* *}\end{array}$ & & $\begin{array}{l}-0.33 \\
0.12 * *\end{array}$ & \\
\hline $\begin{array}{l}\text { Carneiro, } \\
\text { Meghir and } \\
\text { Parey (2007) }\end{array}$ & $\begin{array}{l}\text { UK. National Longitudinal Survey of Youth } 1979 . \\
\text { Cohort } 1958 \text { white children aged } 12-14 \text {. Instruments } \\
\text { used are local tuition fees, unemployment rates and } \\
\text { wages. }\end{array}$ & $\begin{array}{l}\text { Grade repetition } \\
\text { (actual-normal) }\end{array}$ & (no) & & $\begin{array}{l}-0.023 \\
0.005^{* *}\end{array}$ & & $\begin{array}{l}-0.028 \\
0.011^{*}\end{array}$ \\
\hline $\begin{array}{l}\text { Holmlund, } \\
\text { Lindahl and Plug } \\
\text { (2008) }\end{array}$ & $\begin{array}{l}\text { Sweden. Register data. Cohorts of parents 1935-1943. } \\
\text { Children born prior to } 1983 \text { (at } 23 \text { or older). } \\
\text { Reform 1950-1960. }\end{array}$ & $\begin{array}{l}\text { Years of } \\
\text { schooling }\end{array}$ & (no) & $\begin{array}{l}0.20 \\
0.006 * *\end{array}$ & $\begin{array}{l}0.26 \\
0.009 * *\end{array}$ & $\begin{array}{l}0.02 \\
0.061\end{array}$ & $\begin{array}{l}0.15 \\
0.074 *\end{array}$ \\
\hline
\end{tabular}

${ }^{1}$ Results from a restricted sample using the lower part of the parental education distribution (less than 10(12) years of education). 